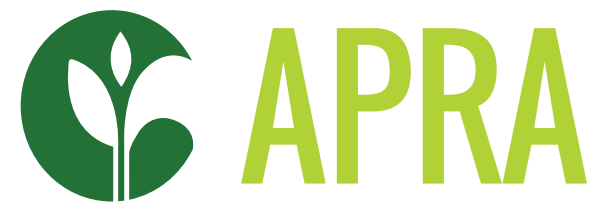

Agricultural Policy Research in Africa

\title{
LONG-TERM PATTERNS OF CHANGE IN THE COMMERCIALISATION OF COCOA IN GHANA: FOREST FRONTIERS AND TECHNOLOGICAL TRANSFORMATION
}

Kojo Amanor, Joseph Yaro and Joseph Teye 


\section{CONTENTS}

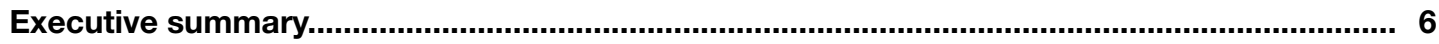

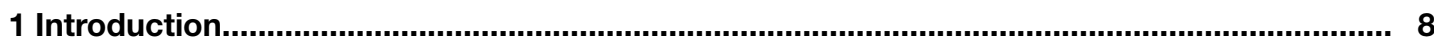

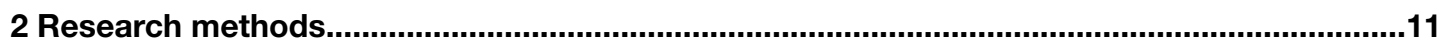

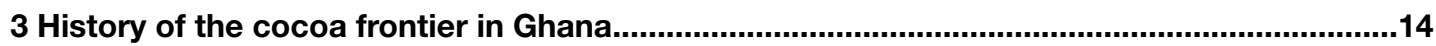

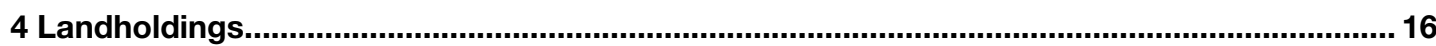

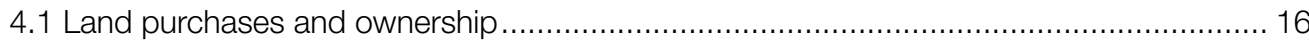

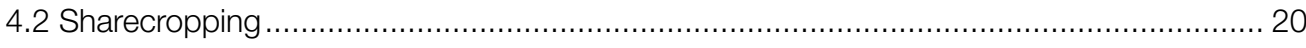

4.3 Contemporary pressures on land appropriation and loss of land ................................ 23

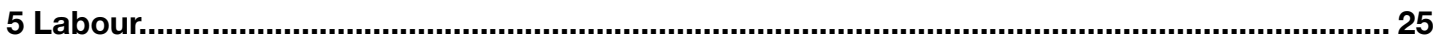

5.1 Contemporary labour relations in Suhum-Ayensuano and Juaboso................................ 26

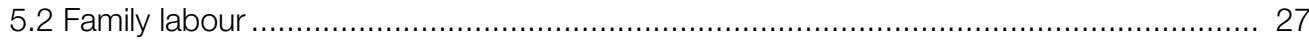

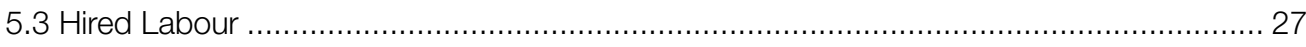

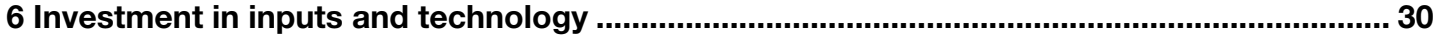

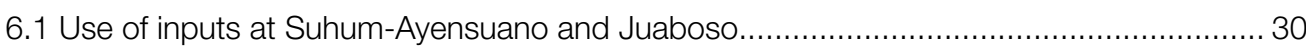

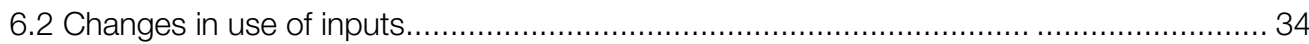

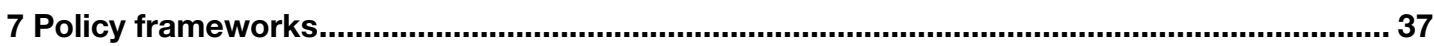

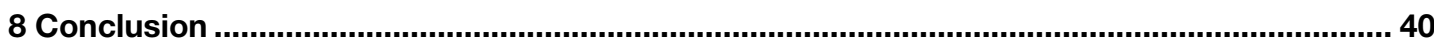

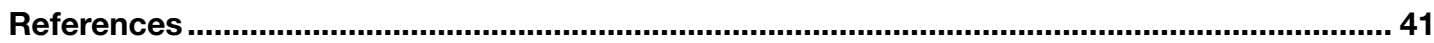

\section{List of tables}

Table 4.1. Land ownership in Suhum-Ayensuano and Juaboso .......................................... 16

Table 4.2. Male and female land ownership in Suhum-Ayensuano and Juaboso ................... 17

Table 4.3. Nature of access to land on cocoa plantations ............................................... 18

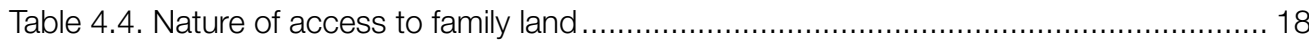

Table 4.5. Occupations of cocoa farmers and their siblings in Suhum-Ayensuano................ 19

Table 4.6. Residence of siblings in the Suhum-Ayensuano area ........................................ 19

Table 5.1 Percentage of men and women farmers using hired labour................................. 26

Table 6.1. Percentage of farmers using or purchasing inputs in Suhum and Juaboso ........... 31

Table 6.2. The sources of cocoa planting materials in Suhum Ayensuano and Juaboso ....... 32

Table 6.3. The relationship between the size of cocoa plantations

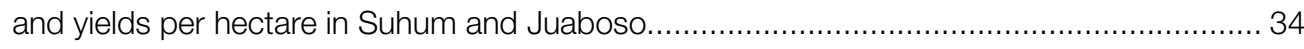

Table 6.4 Comparison of yields of planted hybrid and non-hybrid cocoa ........................... 34 


\section{List of figures}

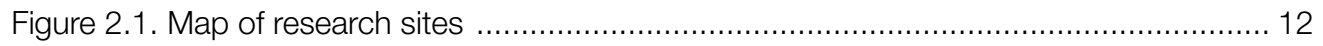

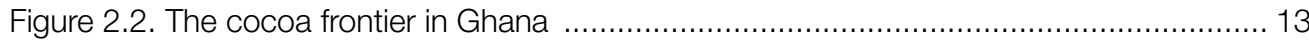

Figure 6.1. Cocoa varieties planted on cocoa farms in Suhum-Ayensuano and Juaboso ..... 32 


\section{ACKNOWLEDGEMENTS}

We are thankful to the field assistants who helped administer questionnaires and interviews: David Atombire Adumbire, Ben Michael Awenam, Nii Adotei Emmanuel Baddoo, Emmanuel Bruku, Fauziyatu Moro, Fobil Ntilam, Alexander Nii Adjei Sowah, Dorothy Takyiakwaa, Dzifa Torvike, and Worlali Torvike. We are also grateful to the farmers and others in the Juaboso, Suhum and Ayensuano municipalities, who were kind enough to give up their time to our questioning.

Kojo Sebastian Amanor is a professor in the Institute of African Studies, University of Ghana. Joseph Awetori Yaro is a professor in the Department of Geography and Resource Development, University of Ghana. Joseph A. Teye is also a professor in the Department of Geography and Resource Development, University of Ghana.

This working paper is funded with UK aid from the UK government (Foreign, Commonwealth \& Development Office - FCDO, formerly DFID). The opinions are the authors and do not necessarily reflect the views or policies of IDS or the UK government. 


\section{ACRONYMS}

COCOBOD

REDD+
Ghana Cocoa Board

Reducing Emissions from Deforestation and Forest Degradation in Developing Countries 


\section{EXECUTIVE SUMMMARY}

The commercialisation of cocoa production in Ghana has a long history in Ghana dating back to the nineteenth century. The process of commercial development in cocoa is well documented and provides an alternative mode to contemporary models of commercialisation rooted in the adoption of modern technology and integration of farmers into markets. The historical development of cocoa was not dependent upon adoption of new technology, but the incorporation of a new crop into existing farming practices, and institutional innovations in land purchases and labour markets. Cocoa farmers took advantage of forested conditions in which cocoa thrive to gain windfall yields. This resulted in cocoa farmers continually moving to new forest frontiers where yields were heaviest and production cost less. In the old production districts cocoa became increasingly vulnerable to disease and pest epidemics, and mature plantations needed to be replanted. However, the costs of rehabilitating and replanting old plantations are much higher than those of clearing new frontiers, and yields are significantly lower. In old frontier areas farmers are faced with much larger weeding requirements and the need to use increasing quantities of agrochemicals to contain diseases and pests. The declining fertility of the soil also results in a marked decrease in yields in newly planted cocoa, resulting in the use of fertilisers. New hybrid cocoa varieties have been introduced to deal with these problems, and to provide high yields in drier conditions, but they depend upon the use of fertilisers and other inputs to perform well.

As long as uncultivated forestland exists, farmers prefer to move to the new frontier to cultivate cocoa rather than rehabilitate old plantations. This opening up of new frontiers results in surplus production of cocoa on world markets and the international price for cocoa adjusts accordingly to the lower costs of production in the new frontiers, undercutting the cost of production in older areas and intensifying the process of frontier colonisation. Historically this has resulted in global shifts in the production of cocoa from South America in the nineteenth century, to the Gold Coast in the early twentieth century and to the Côte D'Ivoire in the 1970s. By the late 1990s, as the forest frontier disappeared in Côte D'Ivoire new competition emerged from Indonesia, Brazil and Malaysia. However, by this period, tropical forests had become scarce and a focus of international environmental protection initiatives. During the 1990s, innovations by smallholder farmers in Côte d'Ivoire and Indonesia led to optimistic assessments of the future of new technologies in cocoa farming. However, these developments have floundered and smallholder cocoa farmers in Côte d'Ivoire and Indonesia are currently confronted by the same ecological crises, disease problems, social crises, and impoverishment faced by Ghanaian farmers.

This working paper critically analyses frameworks for agricultural commercialisation in cocoa through intensification based on the uptake of synthetic inputs and hybrid seeds, by placing agricultural development within a broader framework of the historical development of the frontier in Ghana, and the related problems of ecological and economic crises (related to cycles of boom and bust). The paper is based on two case studies carried out in Suhum and Ayensuano districts of the Eastern Region (one of the oldest growing cocoa areas in Ghana and which continues to produce cocoa) and the Juaboso district of the Western North Region (one of the frontiers opened up from the 1950s to 1970s, which is currently confronted with replanting old cocoa plantations). The study draws on a quantitative survey of 517 farmers and in-depth interviews and focus group discussions with farmers on their perceptions of change in cocoa. The study examines access to land, labour and technology, and how the complex interactions of scarcity of access to physical resources and labour influence farmers' farming strategies and adoption of technology.

\section{Land}

The opening up of new frontiers has been associated with the purchase of forestland by migrant farmers in Ghana. This does not lead to the development of long-term land markets, since in the early stages of cultivation labour is scarce, and land purchasers rely on family members to provide labour in exchange for granting them land rights. Purchased land becomes transformed into family land. The scramble for land in the new frontier areas rapidly leads to land scarcity. As the frontier becomes settled the dominant modes of land acquisition transform into family redistribution and sharecropping. As land scarcity intensifies, families 
have insufficient land to redistribute, and in return for allocation family members are expected to redistribute some of their cocoa earnings to the lineage. This sometimes becomes formalised in sharecropping arrangements within families. Thus, land scarcity results in land becoming a significant cost, in which farmers can give 50 per cent of their production as 'rent' to gain access to land. Since a very small proportion of land is currently acquired through direct land sales, land reforms based on strengthening individual property rights do little to address issues of access to land for the majority of cocoa smallholder farmers.

\section{Labour}

The high cost of access to land and lack of access to family land for many results in scarcity of labour. Extended families are unable to draw upon family labour to the extent they did in the past; they increasingly have to look outside of family land for their livelihoods. Farmers are also resorting more and more to hired labour. However, this labour becomes highly expensive for replanting old cocoa farms. Much of the migrant labour available during the pioneer frontier phase in Ghana have long since relocated to the frontier areas in Côte D'lvoire, resulting in scarce and expensive labour in Ghana. Farmers may be forced to give out their lands to other farmers through sharecropping due to the high labour costs. High labour costs are also reflected in the emergence of credit labour relations.

\section{Technology}

As a result of the relative costs of gaining access to land and labour many farmers struggle to afford investing in hybrid seeds, fertilisers and agrochemicals. While women have less access to modern technologies than men, the vast majority of men have difficulty implementing the recommended cultural practices and achieving noticeable improvements in yields. Lack of capital forces many farmers to make choices between purchasing fertilisers and agrochemicals. In a bid to encourage farmers to take up new technology, cocoa services often provide free technology packages to farmers. This results in the widespread use and adoption of elements of modern technologies. However, most farmers are unable to consistently purchase these inputs. This may have negative consequences, for example, farmers may use hybrids and clear more trees to accommodate hybrid varieties but are unable to follow the recommended fertiliser doses, resulting in lower yields, high disease infestations, and more deforestation. The recommended cultural practices often do not reflect the capital available to farmers, the low prices of cocoa on international markets and do not translate into higher yields.

\section{Policy recommendations}

The dominant policies focus on promoting the intensification of cocoa production by smallholders through the use of modern technologies. The objectives are to encourage higher yields and discourage deforestation through movement into new forests. This does not reflect the actual conditions of production, in which new forest frontiers no longer exist outside of forest reserves. Most cocoa farmers are confronted with the crop's high vulnerability to disease and the need to increasingly apply costly inputs to remain productive. The problems of the environmental rehabilitation of existing cocoa farms also need to be addressed.

One potential solution for smallholders is to focus on creating more varied agroforestry systems, that provide alternative options for farmers, or combine a range of forest and fruit tree species to create a more diverse income source for farmers. These should seek to minimise reliance on the use of agrochemicals and promote a more ecologically conserving and restorative farming system that requires less capital investments and creates a range of viable agricultural and forest commodities, enabling farmers to better deal with fluctuating market prices and boom and bust cycles. There is a need to create a range of solutions, and incremental pathways to a more environmentally friendly and productive farming system that meets the needs of farmers with lack of capital, but who regard cocoa as a viable crop for providing them with a livelihood under particular conditions. More research is needed on the actual conditions under which farmers grow cocoa rather than the potential to achieve exceptional yields with large investments under highly favourable conditions. At present, environmental approaches have been developed which seek to accommodate shade tree planting with a continued focus on achieving higher yields of cocoa through promoting increasing use of inputs and hybrid seeds. However, this approach is not addressing the current crisis of high costs of inputs and drastically falling international prices for cocoa that farmers have faced in recent years. 


\section{INTRODUCTION}

Cocoa production in Ghana has a long history dating back to the nineteenth century, before colonial rule. It built upon commercial oil palm exports in the early nineteenth century. By the 1860s, farmers began looking for alternative crops to oil palm due to competition from southeast Asia and declining prices, and by the 1920s, the Gold Coast had emerged as the dominant cocoa producer in the world, providing 80 per cent of global supplies. This long history of commercial development in Ghanaian cocoa adds three important dimensions to contemporary framings of agrarian commercialisation in Africa. Firstly, the initial commercialisation of cocoa was carried out with little external technological innovation; it was a product of the agro-ecological knowledge of farmers, endogenous institutions used to organise labour and land markets, and the colonisation of a forest frontier. The technological transformations were simple, and agrarian commercialisation was based on social and economic developments rather than the adoption of new technology, opening up increased productivity and rising standards of living. This contrasts with the paradigms of contemporary models of technology-driven agrarian modernisation. Secondly the development of commercialisation in cocoa has risen within the contexts of economic cycles of boom and bust, surplus global production driving down prices in particular epochs, and rising prices leading to the opening of production in new regions of the world, leading to regional shifts in production. The opening of new markets has not only led to economic opportunities and rising standards of living but also to decline in older frontier areas and economic stagnation. This suggests a complex long-term relationship between integration into markets and economic opportunity. Thirdly, ecological factors have been extremely important in shifts in production as the original forest conditions in which cocoa thrive decline, and as the cultivation of a cocoa monoculture leads to disease and pest epidemics. With the decline of the original forest conditions, the cost of cocoa production rose considerably, leading to a shift to new forest frontiers areas and the decline of old centres of production.

Historically, cocoa production has shifted from the Caribbean and Brazil to Fernando Po, to the Gold Coast in the 1920s, and to Côte d'Ivoire in the 1970s. By the 1990s, new production centres emerged in
Indonesia, Malaysia and Brazil as the rapid colonisation of new frontier land in Côte d'Ivoire came to an end. But as world cocoa prices declined during the 1990s, production in these new areas retreated, and even the most promising new production centre in Sulawesi, suffered from the averse effects of price slumps and disease outbreaks related to ecological stress (Clough, Faust, and Tscharntke, 2009). Since the late 1990s, with the decline of new forest frontiers globally and the rise of environmental concerns with protecting remaining forests from agricultural encroachment, the major focus in the cocoa industry has been on promoting intensive cultivation in old plantations areas rather than in uncultivated forests. The use of hybrid varieties, agrochemicals and synthetic fertilisers has resulted in increasing production costs, which has not been reflected in the international price for cocoa. Consequently, a declining proportion of total value of cocoa enters farmers' pockets, resulting in increasing poverty for a significant number of cocoa farmers in Ghana. With few viable alternatives to cocoa, Côte d'Ivoire and Ghana continue to account for over 70 per cent of global production, although yields are often low.

Ruf (2010: 4) has characterised this process of frontier development and cycles of boom and bust as based on 'forest rent'. He argues that in the early years of settlement in new pioneer frontier areas, farmers are able to acquire cheap land (since the area is largely unsettled) and the forest conditions of the land provide large cocoa yields without large inputs of labour in weeding or the need to use fertilisers and agrochemicals. Subsequently, as cocoa matures and soil fertilities decline, the successful renovation of cocoa plantations requires high expenditures on inputs and labour. However, replanted cocoa usually fails to achieve the high yields initially gained in new forest frontiers. This disparity is heightened by the continued existence of new frontier land: as long as this exists farmers prefer to acquire lands in new areas rather than renovate existing plantations. The existence of the frontier enables farmers to meet the demands of the world market cheaply and as a result, international market prices do not reflect the cost of production in old areas. This leads to a shift of production and the exit of old cocoa frontiers. During the late 1990s, as the frontier reached its limits in Côte d'Ivoire, production 
began to shift from the larger Baoule farmers to small migrant planters from Burkina Faso, who intensively cultivated smaller areas of cocoa often on the smallest of margins. Similar developments of more intensive cocoa plantations in the Sulawesi in Indonesia has prompted Ruf (2010) to develop a theory of a transition to a more technologically focused system of intensive smallholder production, providing a pathway out of poverty. A second option noted by Ruf and Schroth (2015) is the movement to diversify production into other crops, or towards agroforestry systems incorporating a diversity of tree crops in response to both the vulnerability of tree crop monocultures to disease and pests and the economic shocks caused by price fluctuations of cocoa on the world market.

There has been considerable research conducted in devising more intensive input-based systems, resulting in the potential for higher yields among West African cocoa smallholder farmers cultivating secondary bush. However, the uptake of these technologies among farmers has been very mixed, and most studies on adoption of inputs among cocoa farmers in both Ghana and Côte d'Ivoire show disappointing rates of uptake of fertilisers, agrochemicals and hybrid varieties by farmers. Consequently, since the early 2000s, the Ghanaian government has played a major role in introducing free hybrid seedlings, subsidies on synthetic fertilisers, and free agrochemical spraying campaigns. Odijie (2018) argues that the provision of subsidised inputs to farmers represents a desperate attempt by government to keep farmers in cocoa production, when an increasing number of them are abandoning cocoa for other crops that require less expenditure on inputs, such as rubber and oil palm. He argues that very little of the value of cocoa currently trickles down to cocoa farmers and that the government ends up spending most of the revenues it gains from taxes on assisting the cocoa sector. He sees the government as essentially subsidising the transnational cocoa corporations that absorb most of the value produced in cocoa. This is substantiated by data collected in the Côte d'Ivoire by Fountain and Huertz-Adams (2015). They estimate that cocoa farmers only receive about 6 per cent of the total value of cocoa. They also point to structural poverty within the cocoa sector and estimate that over 60 per cent of cocoa farmers in Côte d'Ivoire are impoverished. Fairtrade International (2018) has also estimated that only 12 per cent of Côte d'Ivoire cocoa farmers receive a living income of over US\$2.50 per day. Low producer cocoa prices also led to tensions within the cocoa industry in 2019, when the governments of both Côte d'Ivoire and Ghana threatened to boycott the sale of cocoa unless international buyers raised minimum prices. They eventually settled on implementing a Living
Income Differential, in which the governments would pay farmers the equivalent of US\$400 when prices fell below US\$2,600 pert (Africa Research Bulletin, 2019).

Nevertheless, the plight of cocoa farmers is not unique, and most staple crops produced for international markets are subject to price volatility, cycles of boom and bust, declining returns of proportion of value to farmers, and the ecological consequences of largescale monocrop production (Daviron and Ponte, 2005). In contrast with many other industrial tree crops, the ability of cocoa to thrive in forest shade enables it to adapt remarkably well to agroforestry systems in which a variety of trees are cultivated and preserved (Schroth and Harvey, 2007; Laird, Awung and Lysinge, 2007). However, in the quest to maximise yields, modern cocoa hybrids have been bred to be less tolerant of shade than the older varieties. The viability of developing cocoa agroforestry systems that preserve many forest elements and other fruiting trees alongside cocoa and which minimise the use of chemical inputs (which often have a harmful effect on the forest fauna), needs to be explored as a serious option that can meet the needs of smallholder cocoa farmers, while addressing environmental and climate change policy frameworks.

Contemporary policy concerns with deforestation and climate change have resulted in a growing body of research examining the viability of cocoa as a component of diverse agroforestry systems (Gockowski and Sonwa, 2011; Asare et al., 2014; Gyau et al., 2015; Asare and Anders, 2016). These studies can be divided into those that seek to incorporate more shade trees into existing intensive cultivation of cocoa, with high use of fertilisers and agrochemicals (Gockowski and Sonwa, 2011), and those which seek to create more diverse agroforestry systems that incorporate a diversity of income generating crops and rely less on agrochemicals, creating a more friendly agroecology for bird and insect populations (Schroth and Harvey, 2007; Gyau et al. 2015; Asigbaase et al., 2019).

This paper examines debates about the commodification of cocoa production, changing values of relative factors of production, ecological crises, and shifts in frontiers in the light of a comparative case study of two cocoa producing areas in Ghana: the Suhum-Ayensuano area and Juaboso. The SuhumAyensuano area is one of the oldest cocoa growing frontiers of cocoa on the fringes of the southeastern forests of Ghana. Juaboso, which is near the border of Côte d'Ivoire, is one of the new frontier areas to develop in western Ghana from the 1950s to the 1970s. Following an outline of the development of the cocoa frontier in Ghana and its ecological consequences, this study compares access to land, labour and 
technology in the two study areas. It examines the interaction of the commodification of land and labour with the role of extended families in agricultural production, and the transformations in the factors and relations of production that are related to the nature of frontier development and its subsequent decline. It also examines processes of social differentiation; the extent to which new technologies are taken up by farmers; and the extent to which technology shapes the emergence of new forms of agrarian accumulation or fails to address the underlying problems that have emerged within the cocoa industry. These problems include declining agroecological conditions, deforestation, increasing vulnerability of monocrop production to disease and pests, and declining returns to farming as more capital is expended in labour, seeds, inputs, and fertilisers. 
This study is based upon a combination of quantitative and qualitative research methods carried out in ten settlements in the Suhum and Ayensuano municipal districts (which formerly constituted the Kraboa Coaltar district and will be referred to as SuhumAyensuano) of the Eastern Region and the Juaboso district in the recently created Western North Region (originally Western Region). Quantitative data are used to provide insights into the prevalence of particular types of relations and normative practices found in the qualitative work, and to explore the relationship between different sets of factors. Beyond this, the study also builds upon historical dimensions from secondary works, examining the changes and transformation within institutions and practices in the context of changing patterns of frontier expansion.

Focus groups discussions and in-depth interviews were used to gain qualitative data. In the Ayensuano and Suhum districts following initial focus group discussions, in-depth interviews were held with thirty farmers (including seven women and 23 men) in the settlements of Bekoekrom in Ayensuano and Ayisaa and Brong Densuso (a neighbouring settlement) in the Suhum district. An interaction was also held with the Cocoa Services Division at Suhum. In Juaboso, nine focus group discussions and 61 in-depth interviews were held with 56 farmers and five labourers, and 13 life histories were captured with older cocoa farmers at Juaboso Nkwanta, Abrokofe, and Antobia. Seven interviews were also held with Cocoa Health and Extension Division Officers and purchasing clerks. Twenty-four farmers interviewed were female; all labourers and loading boys were male; one out of five purchasing clerks was female; and both Cocoa Health and Extension Division Officers were male. Five out of the 13 life histories were of female farmers. The communities were dominated by Sefwi indigenes with fewer migrants, although there were many intermarriages between Akan and Sefwi groups. All labourers interviewed were migrants from the north, Volta and Krobo areas. Based on preliminary insights from the qualitative research, a structured questionnaire was designed and used to collect data from 517 farmers selected from 10 farming communities. This included the settlements of Bekoekrom, Ayisaa,
Brong Densuso, Sowartey, Duodokrom and Esiam in Suhum-Ayensuano, and Juaboso Nkwanta, Abrokofe, Antobia, Aferewaa and Boizan in Juaboso. A total of 241 people were interviewed at Suhum-Ayensuano, including 161 men and 77 women. In Juaboso 276 people were interviewed, including 172 men and 77 women. Women made up 35 per cent of the sample.

The quantitative questionnaire sought to obtain information from farmers on temporal changes in land tenure and labour arrangements, use of inputs, output of cocoa, profitability of cocoa farming, and government policies. The sample size in each of the 10 communities was proportional to the community's total population. In each farming community, the estimated total number of the houses was divided by the pre-determined sample size to obtain the sampling interval that was used to select the houses that participated in the study. Generally, one farmer was interviewed in a selected house, although in a few instances where more than one farmer was interviewed these were selected on the basis of gender and age representation. STATA was used to analyse the quantitative data. 
Figure 2.1 Map of research sites

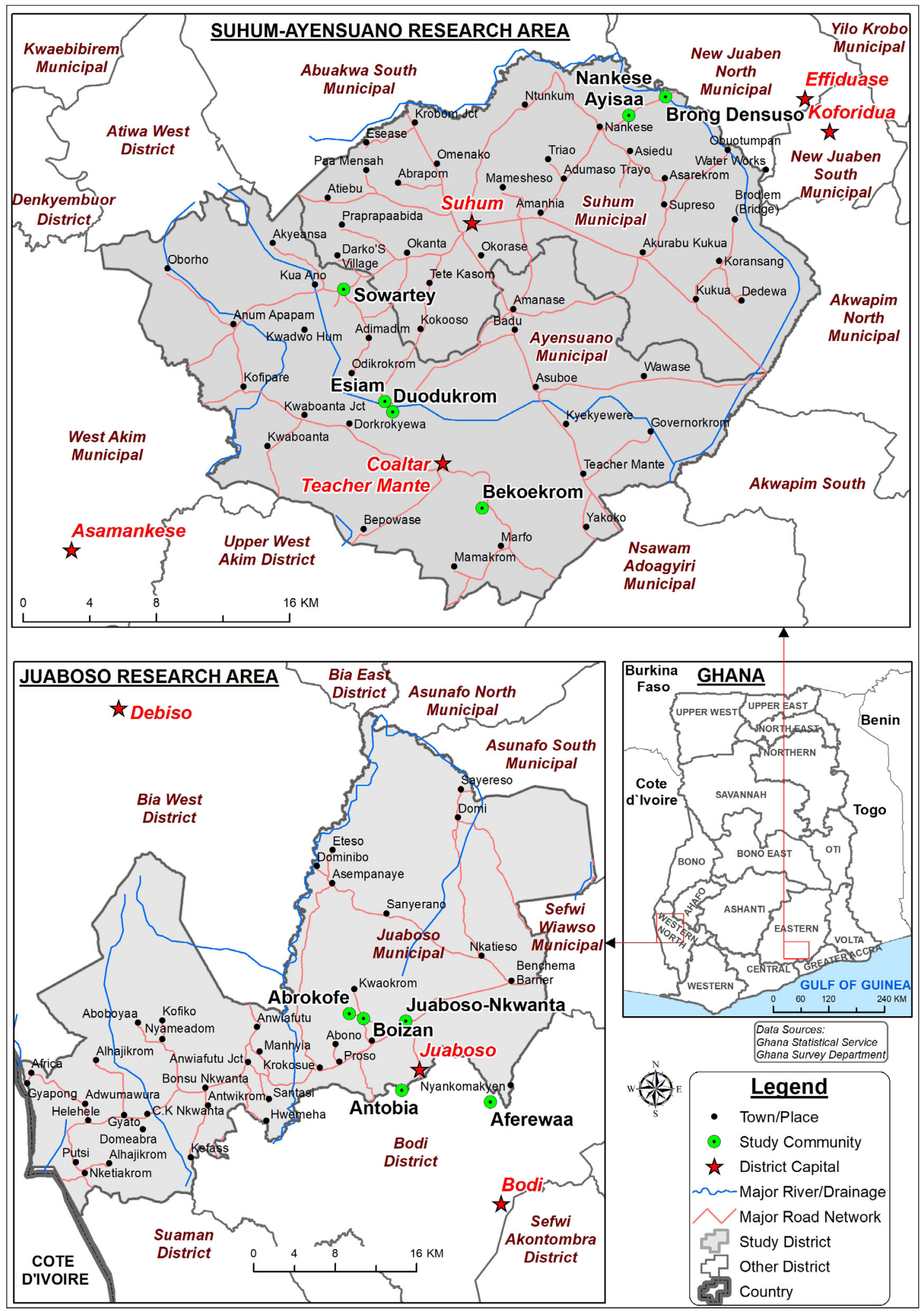

Source: () Ghana Statistical Services, adapted by authors. 
Figure 2.2: The cocoa frontier in Ghana

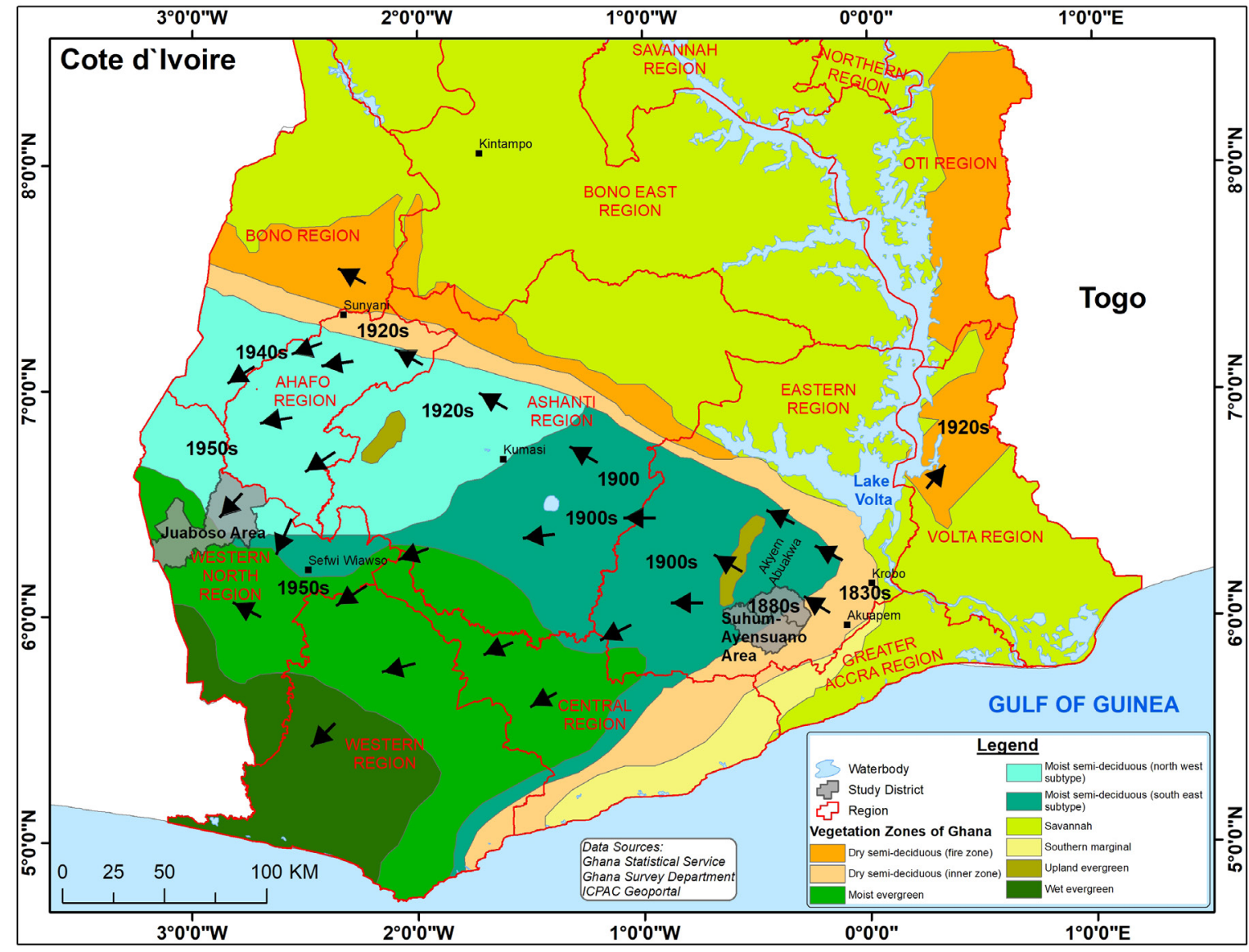

Source: (c) Ghana Statistical Services, adapted by authors. 


\section{HISTORY OF THE GOCOA FRONTIER IN GHANA}

The origins of commercial export crop production in Ghana can be traced to oil palm production in southeastern Ghana in the early nineteenth century in the Krobo and Akuapem areas. Palm oil was exported to Europe from the 1820s. This was based on the establishment of large plantations by wealthy traders and chiefs, some of whom purchased land from neighbouring peoples within the area, giving rise to land sales that date back to the early nineteenth century (Hill, 1963; Johnson, 1964; Amanor, 2010). These large plantations were cultivated with extended family and domestic slave labour (Johnson, 1964; Amanor, 1994; Austin, 2005). Traders also accumulated capital in the kola nut trade and wild rubber tapping - capital which was also invested in the development of cocoa (Hill, 1963; Arhin, 1980). During the 1860s declining international prices for palm oil, resulting from southeast Asian entry into export production, led Gold Coast producers to shift to cocoa, which emerged as the most profitable export crop. Since cocoa prefers wetter forest conditions and land markets had emerged to purchase land for oil palm during the early nineteenth century, many aspiring cocoa farmers in Akuapem were able to purchase land in more forested areas within Akyem, in the present Suhum-Ayensuano area (Hill, 1963). These farmers moved into areas where there was little agricultural accumulation of capital, and where chiefs were willing to transact land with migrants, setting off a process of pioneer frontier cultivation of cocoa.

According to Hill (1963), two significant social institutions developed for the purchase of land. Among the richest planters from Akuapem towns, a small group of associates purchased large tracts of land, which they parcelled out to matrilineal relatives who helped them to convert and settle the forest, and who provided essential labour services for them. In other areas, where there was less capital accumulation within lineages, prospective cocoa farmers formed land-purchasing companies, which would raise capital among the members to buy large tracts of land from chiefs. The land was subsequently shared among the group according to financial contribution (Hill, 1963). As the value of cocoa became recognised, its cultivation spread among indigenous smallholders in the Akyem area on their family land (Beckett, 1944; Okali and Kotey, 1971; Okali, 1983). ${ }^{1}$

The expansion of cocoa also attracted migrant labour to the main cocoa growing areas. This included a significant number of migrants from areas designated by colonial authorities as labour reserves in northern Ghana and the surrounding Sahelian French colonies in which males were forced to migrate to gain employment to meet tax obligations (Amanor, 1994). The cocoa sector was regarded as one of the most favourable sectors to work in. This availability of labour enabled enterprising cocoa farmers to expand their production into new areas. Old established plantations were often placed under migrant sharecrop labourers, who were remunerated with a third share of the yield, while family labour and monetised labour was recruited to work in creating plantations in new frontier areas. Enterprising farmers sought to minimise cash outlays so that they could invest savings in the purchase of new land.

The combination of family and sharecrop labour enabled the rapid colonisation and expansion into new forest frontiers by capital accumulating farmers. By the 1920s, cocoa was widely cultivated in Ashanti by large numbers of Asante large-scale farmers and smallholders, who had sufficient capital to hire migrants (Austin, 2005). In contrast, in the Western Region, which had much lower rates of capital accumulation and lacked locally available labour, the expansion of cocoa had to await the arrival of migrants with capital (Boni, 2005).

The opening up of new frontiers of cocoa production by migrant farmers facilitated the uptake by locals and by smallholders. The demands of migrant farmers for paid and sharecrop labour opened up labour migrations, providing opportunities for local farmers to hire labour to convert forest into cocoa. Local landlords and chiefs released land to migrants to convert into cocoa production on share contracts. In these contracts, the resulting cocoa plantation would be shared between landlords and tenants, with tenants claiming their share as their own property which could be inherited

This history is presented in more detail in Amanor, Yaro and Teye (2020). 
by their children. The movement of local smallholders into cocoa farming on family land also led to the rapid expansion of family land and growing land shortages in the frontier areas, encouraging migrations to newer frontiers.

By the 1940s, a significant percentage of cocoa plantations in the Eastern Region (or Eastern Province of the Gold Coast) had matured and become increasingly vulnerable to disease, particularly swollen shoot (a plant pathogenic virus of the Caulimoviridae family which leads to declining yields and kills cocoa trees within a few years), which developed into a serious epidemic (Hill, 1963). Given the costs of replanting cocoa, many farmers shifted their efforts into the Western Region during the 1950s, and migrant labour began to relocate to this area. This led to an increasing shortage of labour in the Eastern Region. Many impoverished farmers also migrated to the west, where they worked as wage labourers or sharecrop labourers (Arhin, 1988).

By the 1970s, cocoa in the Western Region had to compete with the opening up of new cocoa frontiers in southwest Côte d'Ivoire. The rapid expansion of Ivoirian cocoa resulted in an oversupply in international markets and rapidly declining prices. More favourable production conditions (including access to ownership of land at cheap prices) in the new frontier areas of Côte d'Ivoire (Chauveau and Léonard, 1996) resulted in most of the Sahelian migrant labour force relocating from Ghana to the Côte d'Ivoire. This led to labour shortages in Ghana and increasingly expensive labour. Farmers needed to resort more to daily casual labour rather than annual contracts and abusa caretakers hired labourers or farm managers who receive a third of the proceeds of the cocoa when it is harvested and marketed at the end of the farming year. ${ }^{2}$ By the late 1990s, the rapid expansion of Ivoirian cocoa resulted in the disappearance of new forest frontiers and both Ghana and Côte d'Ivoire were now faced with the task of maintaining cocoa production through replanting old plantations in secondary forest bush. This involved a transition to new technologies, including hybrid seedlings adapted to drier conditions, use of fertilisers on which the hybrids were dependent, and the regular use of agro-chemicals against diseases and pests.
The uptake of new technologies has been slow and problematic. The increasing cost of gaining access to land and labour has left farmers with few resources to invest in inputs. Although it has been demonstrated that farmers can achieve much higher yields through these investments, these have not necessarily translated into practice due to the particular production conditions on farmers' fields and the risks they face.

The increasing shortage of land in Ghana has also transformed family labour in cocoa production. An increasing number of farmers are faced with the prospects of acquiring land outside of the extended family lands. Since the 1970s, studies have documented the increasing conflicts between family members over access to cocoa plantations (Okali, 1983; Amanor, 2010). Insecurity and contestations around access to family land have resulted in growing numbers of farmers seeking land outside the lineage on sharecropping terms, or in families releasing land to kin under sharecropping arrangements, since they gain preferential access. The decline of family land has also led to the transformation of family labour, as those without land or security in land seek land elsewhere, turn to wage labouring, or move into other occupations. This results in increasing expenditure on labour by farmers who can no longer rely on family labour. The higher labour requirements and costs involved in rehabilitating plantations often absorb significant capital. This prevents the majority of farmers from investing in new hybrid varieties and inputs, particularly since increasing investment in inputs is not reflected in increases in international prices. Thus, the trend for an increasing number of farmers is one of struggling to continue to produce on small margins, rather than a discernible process of upgrading farm production. This is because in many areas there are few attractive alternative livelihood options to cocoa farming available.

The following sections draw upon field data from the Suhum-Ayensuano and Juaboso areas to examine the main emerging trends in access to land, labour and technology and the allocation of resources in cocoa farming. This is examined in relation to the comparative historical development of the frontier in both areas, and the commodification of land, labour and technology.

2 Abusa denotes a third share (literally 'divided into three') and abunu, a half share ('divided into two'). This is applied to both land renting and hiring of labour. In the labour system the caretaker receives a third share of the harvest for maintaining, weeding, harvesting an established cocoa farm. There are several variants of the tenancy system, in which the tenant may receive a half share or a two-thirds share. In the past, where the tenant created a cocoa plantation from forest and managed the farm, they received two thirds of the harvest. In another variation, the plantation created by the tenant was divided between tenant and landlord and the landlords were responsible for managing their portion. In this arrangement, the tenant received one third of the land. In recent times, the dominant sharecrop tenancy arrangement is a half share between tenant and landlord (Hill, 1956; Amanor, 2010). 
The dynamics in the development of frontiers have led to different patterns of landholding in the Juaboso and Suhum-Ayensuano districts. The Suhum-Ayensuano area is part of a much older frontier, dating to the late nineteenth century, which has seen an early rapid expansion of cocoa followed by an ecological crisis emanating out of the swollen shoot epidemic in cocoa in the 1950s. This has resulted in the outmigration of the wealthier cocoa farmers to newer frontier districts and declining yields for cocoa. The relative age of cocoa farms in this area has resulted in large numbers of farmers with claims and interests in lineage land, which is well beyond that which the land can cater for. The low productivity of cocoa in this area, in comparison to new frontier areas, has resulted in many descendants of wealthy farmers shifting out of cocoa into other occupations. These factors result in a highly mobile farming population, a prevalence of small plots, and high incidences of sharecropping. In contrast, in Juaboso, the phase of senescence of cocoa and replanting is a contemporary experience. The much later emergence of cocoa has resulted in lower land pressures than in the Suhum-Ayensuano area and in more farmers accessing land through inheritance and family relations.

These differences are reflected in the size of farm holdings in the two districts. In the quantitative survey only 35 per cent of farmers in Suhum-Ayensuano had landholdings of 2.5 ha or more, compared to 65 per cent of farmers at Juaboso. Forty-two per cent of farmers surveyed at Juaboso have holdings of over tha compared to 13 per cent of farmers in Suhum-Ayensuano.
These pressures on land within Suhum-Ayensuano have also significantly impacted on women's access to land. Thirty-five per cent of women possessed less than 1ha of land compared to 13 per cent of males, while at Juaboso 10 per cent of women had less than tha of land compared to 4 per cent of men. At Juaboso, 27 per cent of women had plots of land between 4-8ha compared to 4 per cent of women in Suhum-Ayensuano. This suggests that as land becomes scarce, less is distributed to women.

There is also significant inequality in the distribution of land plots by age at Juaboso, where 65 per cent of farmers within the over 65 age group and 41 per cent of farmers within the 50-64 age groups possessed lands over 4ha, as compared to 13 per cent of farmers under 30. In contrast, at Suhum-Ayensuano the vast majority of farmers in all age categories farmed less than 2.5ha of land. Only a few farmers belonging to large landowning families had access to large plots of land.

\subsection{Land purchases and ownership}

Patterns of land ownership in the cocoa sector are closely related to the process of frontier development. Migrant farmers move into unsettled forest areas after acquiring tracts of land from chiefs, in areas in which there was previously little commodification of land or development of commercial agriculture. This process of frontier development has resulted in a rapid transformation of land into individual purchased property. This has largely occurred in forested areas in which there had been little development of settlements and infrastructure. The early migrants colonising these

Table 4.1. Land ownership in Suhum-Ayensuano and Juaboso

\begin{tabular}{|l|l|l|l|l|}
\hline Hectares & $\begin{array}{l}\text { Suhum-Ayensuano } \\
(\%)\end{array}$ & $\begin{array}{l}\text { Juaboso } \\
(\%)\end{array}$ & $\begin{array}{l}\text { Total } \\
(\%)\end{array}$ & No. of farmers \\
\hline Under 1ha & 20.3 & 5.8 & 12.6 & 65 \\
\hline $1-2.4$ ha & 44.8 & 30.4 & 37.1 & 192 \\
\hline $2.5-4$ ha & 21.6 & 22.1 & 21.9 & 113 \\
\hline 4.1-8ha & 11.2 & 31.5 & 22.1 & 114 \\
\hline Over 8ha & 2.1 & 10.2 & 6.3 & 33 \\
\hline Total & 241 & 276 & 517 & 517 \\
\hline
\end{tabular}

Source: Authors' own 
areas needed to develop social support networks to create the basic infrastructure for new settlements and for clearing unsettled forest. The migrant farmers formed companies in their hometowns for the joint purchase and settlement of land or drew upon large extended lineage networks to settle the area, as in the matrilineal lands described by (Hill, 1963) in south-east Ghana. As cocoa farming spread and was taken up by the indigenous smallholder farmers, the areas of local lineage lands expanded, diminishing the areas available for migrant purchases, and leading to the foreclosure of the frontier, and then its expansion into other areas. Land purchases are characteristic of a particular phase of the opening up of frontiers; they eventually become less significant as a means of gaining access to land as migrants subsequently redistribute land to their kin, and as local smallholders move into the cultivation of cocoa on their own lineage lands. ${ }^{3}$

Due to the mobilisation of lineage or family labour in transforming forest into cocoa plantations, and because of the large demand for land, the early land transactions did not lead to the growth of permanent land markets or the perpetuation of land sales. As the areas of uncultivated forests were brought under cultivation, land sales were increasingly replaced with the family redistribution of land through inheritance and gifts of land, and through the rise of sharecropping. Portions of the purchased land were distributed to wives and children and other relatives willing to work on cocoa cultivation, with the understanding that they would be allocated parts of the land in the future as their own cocoa plantations (Hill, 1963; Okali, 1983). The few land transactions that continue to occur are usually distress sales to meet exceptional expenditures and difficulties.

The increasing scarcity of land as the frontiers mature results in an unwillingness of those who have purchased land to sell surplus land on the market according to their farming needs, since replacement costs in the future are likely to be much higher. Thus, land sales do not tend to operate as a means of distributing land from land-surplus to land-scarce farmers, as it has been theorised in the literature on the development of land markets (Deininger, 2003). Land sales have usually operated as a means of enabling uncultivated land in frontier areas to be brought under cultivation in areas where the capital and labour requirements were originally lacking, and to kick-start a process of export crop production. Since agricultural labour tended to be scarce in new frontier areas, the early generation of cocoa farmers that opened up new frontiers usually relied on family labour. Family members acquired interests and rights in the land through their contribution to the creation of the cocoa plantations on which they worked. The large number of family members who came to develop interests and claims of the cocoa property created difficulties for future land sales. Many of the early land purchasers also relied on capital that had been accumulated in their families, or joined together with other family members to purchase land, which also resulted in their lineages having interests and claims to a stake in the land. Since inheritance rules are not based on primogeniture (inheritance by one predetermined heir) individually purchased property tends to be transformed back into family property as it becomes shared among various extended family members with claims upon the land (Hill, 1963; Okali, 1983; Amanor, 2010).

A large number of migrants were attracted to the new cocoa frontiers in which they hoped to make a better living. This included many labourers and aspiring farmers with insufficient capital to invest in land. With the emergence of a significant labour force within the area, the landowning chiefs and elders began to allocate land on sharecrop arrangements to aspiring cocoa farmers. This often involved dividing the farm into shares between the tenant and landlord in which

Table 4.2. Male and female land ownership land in Suhum-Ayensuano and Juaboso

\begin{tabular}{|c|c|c|c|c|c|}
\hline Hectares & Suhum-A & & Juaboso & & Total \\
\hline Hectares & Male (\%) & Female (\%) & Male (\%) & Female (\%) & No. of farmers \\
\hline Under 1ha & 13.4 & 35.1 & 3.5 & 9.6 & 65 \\
\hline 1-2.4ha & 45.7 & 42.9 & 26.2 & 37.5 & 192 \\
\hline 2.5-4ha & 23.8 & 16.9 & 21.5 & 23.1 & 113 \\
\hline 4.1-8ha & 14.6 & 3.9 & 34.3 & 26.9 & 114 \\
\hline over 8ha & 2.5 & 1.3 & 14.5 & 2.9 & 33 \\
\hline No. of farmers & 164 & 77 & 172 & 104 & 517 \\
\hline
\end{tabular}

Source: Authors' own

$3 \quad$ Locals can also gain land by clearing unclaimed forestland and cultivating it. Subsequently, through inheritance, it is transformed into family land. 
the tenant's share became recognised as their own property. A common arrangement in the Eastern Region in the colonial period was for the landlord to gain two thirds of the plantation and the tenant one third (Hill, 1956). In contrast, where the tenants continued to manage and farm the cocoa plantation they had created, they would receive two thirds of the cocoa yields, but the land continued to be recognised as the landlord's property. This enabled landowners to convert land ownership into cocoa plantation ownership. For landless migrants without sufficient capital to purchase land, sharecropping provided an avenue to gaining access to it. In the Western Region from the 1960s and 1970s, the dominant land sharing arrangement was a half share between landlord and tenant (Boni, 2005).

The lack of continuous development in land markets is reflected in the nature of access to farm plots reported by farmers in the quantitative survey. Only 5 per cent of the current cocoa plantations were acquired through direct purchase. ${ }^{4}$ The dominant means of gaining access to land was through family allocation of land, which accounted for 68 per cent of the cocoa plantations, and through sharecropping, which accounted for 21 per cent of cocoa farm plots. There were significant differences in the proportions of farmers gaining access to land through family allocation and through sharecropping within the two areas. In Suhum-Ayensuano 52 per cent of cocoa farms were gained through family allocations and 42 per cent through sharecropping; at Juaboso 80 per cent of cocoa farms were acquired through family redistribution and only 5 per cent through sharecrop arrangements (see Table 4.3). However, family land may also be given out to family members on a sharecrop arrangement. Ten per cent of cocoa plantations under family land in Suhum-Ayensuano were granted under sharecropping arrangements, compared to 4 per cent in Juaboso. The higher frequency of sharecropping arrangements on family land at Suhum-Ayensuano reflects the scarcity of land.

\subsection{Women's access to land and land scarcity}

Women's access to land varies according to patterns of development in the cocoa frontier. These patterns of development include areas in which land was acquired by relatively well-to-do migrants and areas in which smallholder farmers moved into cocoa once the initial infrastructure was set up, including when labour became available and a marketing structure was put in place by the early large-scale farmers (Hill, 1963). Women were largely absent among the initial Akuapem farmers who acquired large portions of land in the Akyem forests, although some were allocated plots of land by their land-acquiring relatives (Hill, 1963).

Table 4.3. Nature of access to land on cocoa plantations

\begin{tabular}{|l|c|c|c|c|}
\hline Source of land & $\begin{array}{l}\text { Suhum-Ayensuano } \\
\text { (\% of farm plots) }\end{array}$ & $\begin{array}{l}\text { Juaboso } \\
\text { (\% of farm plots) }\end{array}$ & $\begin{array}{l}\text { Total } \\
\text { (\% of farm plots) }\end{array}$ & No. of farm plots \\
\hline Family land & 52.4 & 79.8 & 68.0 & 51 \\
\hline Purchased & 4.7 & 5.5 & 21.0 & 207 \\
\hline Sharecrop & 42.2 & 5.0 & 5.8 & 57 \\
\hline Other & 0.7 & 9.6 & 984 & 984 \\
\hline No. of farm plots & 424 & 560 & & \\
\hline
\end{tabular}

Source: Authors' own

Table 4.4. Nature of access to family land

\begin{tabular}{|l|c|c|c|c|}
\hline Source of land & $\begin{array}{l}\text { Suhum-Ayensuano } \\
\text { (\% of farm plots) }\end{array}$ & $\begin{array}{l}\text { Juaboso } \\
\text { (\% of farm plots) }\end{array}$ & $\begin{array}{l}\text { Total } \\
\text { (\% of farm plots) }\end{array}$ & No. of farm plots \\
\hline Inherited & 82.8 & 64.2 & 70.3 & 470 \\
\hline Gift & 6.8 & 33.1 & 24.4 & 163 \\
\hline Sharecrop & 10.0 & 1.6 & 4.3 & 29 \\
\hline Other & 0.5 & 1.1 & 0.7 & 6 \\
\hline No. of farm plots & 221 & 447 & 668 & 668 \\
\hline
\end{tabular}

Source: Authors' own

$4 \quad$ The data focuses on plantations rather than farmers because farmers may own multiple cocoa farms acquired under different arrangements. 
Similarly, women were largely absent from the landpurchasing companies in which farmers contributed to the purchase of large plots of land that were subsequently divided among contributing members. However, before the advent of cocoa farming, women played an important role in forest agriculture and men often cleared tracts of land that they allocated to women to farm. In the 1940s, Field (1948) records that in Akyem, fathers would clear land and allocated it to their daughters to farm. In the late 1950s, Hill (1963) recorded the significant participation of women in cocoa farming in Akyem villages (in which land was held by lineages and acquired through clearing forest). Hill and McGlade (1957) also reported the difficulties women experienced in gaining land as cocoa farming expanded, and the attempts of women to protect women's access to land by redefining it as women's property that passes from mother to daughters. Amanor (2000) found daughters fiercely defending their rights to their mothers' land from sons who were experiencing difficulty in gaining land access through their fathers and maternal uncle and who were turning towards their mothers for land. The daughters argued that if their mother acceded to her sons' requests the land would eventually pass to the sons' sons, who were not event members of the matrilineage or their nephews. In the early 1980s, Okali (1983) reported increasing conflicts between husbands and wives and their children over the inheritance of cocoa farms. The wives and children expected to be compensated with cocoa farms for the labour they had exerted in managing the farm, while the matrilineal relatives of the husband sought to exclude his wife and children since they were not part of the matrilineage. These conflicts over land reflected the increasing scarcity of land, and its adverse impact on women's and youth's access to land. The existing rights women have gained in land may become contested with growing scarcity of land, which results in competition between existing rights holders and more exclusive access to land.

One of the problems that arises from focusing on commercialisation within a specific sector, is that it does not contextualise the problem of access within the wider population. Thus, the attempt to gain wider female representation within a category of cocoa farmers tends to overestimate the participation of women in cocoa, since it excludes or does not focus on the experience of women outside of the cocoa sector or particular food commodity under investigation. To compensate for this, research in the SuhumAyensuano area attempted to record the livelihoods and locations of the various siblings of interviewed farmers. However, many of the interviewers could not

Table 4.5. Occupations of cocoa farmers and their siblings in Suhum-Ayensuano

\begin{tabular}{|l|c|c|c|c|}
\hline Occupation & Male (\%) & Female (\%) & Total (\%) & No. of farmers \\
\hline Farming cocoa in home village & 46 & 33 & 41 & 45 \\
\hline Farming cocoa elsewhere & 3 & 4 & 4 & 4 \\
\hline Food crop farming & 3 & 0 & 2 & 2 \\
\hline Trader, artisan, self-employed informal sector & 26 & 49 & 36 & 39 \\
\hline Professional & & & & \\
\hline Retired & 6 & 0 & 4 & 4 \\
\hline Don't know & 3 & 0 & 2 & 2 \\
\hline Other & 19 & 14 & 15 & 8 \\
\hline Total & 65 & 45 & 110 & 110 \\
\hline
\end{tabular}

Source: Authors' own

Table 4.6 Residence of siblings in the Suhum-Ayensuano area

\begin{tabular}{|l|c|c|c|c|}
\hline Residence & Male (\%) & Female (\%) & Total (\%) & No. of siblings \\
\hline Same settlement & 82.8 & 64.2 & 70.3 & 470 \\
\hline Other rural settlement & 6.8 & 33.1 & 24.4 & 163 \\
\hline Nearby town & 10.0 & 1.6 & 4.3 & 29 \\
\hline Accra & 0.5 & 1.1 & 0.7 & 6 \\
\hline Town in another region & 221 & 447 & 668 & 668 \\
\hline Total & 221 & 447 & 668 & 6 \\
\hline
\end{tabular}

Source: Authors' own 
remember all their siblings and were not aware of their current livelihoods. This was complicated by the fact that there may be many half-siblings arising from the multiple marriages of fathers. As a result, only 16 of the interviewed farmers in the qualitative survey at SuhumAyensuano were able to produce comprehensive information of all their siblings. Even this does not seem to be fully accurate though, since of the total 110 recorded cases, only 45 were women, which suggests that some female siblings may have been forgotten - it is unlikely that there was such a disproportionate number of males among siblings. Forty-one per cent of these siblings continued to farm cocoa in the village, while 36 per cent had moved into trading, artisanal and informal sector occupations (see Table 4.5). Only 4 per cent were farming cocoa elsewhere, and only 2 per cent had shifted out of cocoa into food crop farming. The movement into trading, artisanal and informal sector occupations was most significant among women, with 49 per cent of women involved in these sectors compared to 26 per cent of men. Conversely, 46 per cent of men were farming cocoa in the village compared to 33 per cent of women. This movement into the trading and artisanal sectors was associated with migration out of the village. While 40 per cent of the siblings resided in the village and 9 per cent had moved to other rural sectors, 30 per cent had moved to nearby towns and 20 per cent to Accra (see Table 4.6). Again, this was more significant among women, of which 36 per cent resided in nearby towns compared to 22 per cent of men. This suggests that there is a significant movement out of cocoa arising from either lack of availability of land or lack of capital and labour to carry out replanting and rehabilitation of cocoa. However, we do not know the previous distribution of rural people within cocoa, and Hill's (1963) maps of land holdings show the overwhelming dominance of men in ownership and inheritance of land. Hill also documents that many farmers left their cocoa plantations following swollen shoot disease in the 1950s, and often gave it out to more distant relatives, presumably with less access to land of their own. This suggests processes of better-off farmers moving out of cocoa following swollen shoot, and the transfer of lands to other categories of farmers, foreshadowing the emergence of sharecropping.

\subsection{Sharecropping}

The higher incidence of sharecropping in SuhumAyensuano than in Juaboso is related to complex historical factors, rooted both in land pressures and land shortages in the Suhum-Ayensuano area, but also in the replanting of old cocoa and the history of ecological crises that started with the swollen shoot epidemic of the 1950s. These crises resulted in an outmigration of cocoa farmers to new western frontier land, and a movement out of cocoa into other crops, or out of farming into other occupations. Farmers experienced increasing difficulty in replanting cocoa. Those farmers unable to meet the increasing labour requirements and costs were forced to lease their land out to other farmers, who have sufficient labour and capital to carry out replanting, on a sharecrop arrangement.

Hill (1963, p. 11) noted that the 1950s swollen shoot epidemic resulted in a shift in access to land to many people without direct claims on the land:

'Many farmers prefer not to clarify their relationship to a farm over which they have assumed effective charge - presuming that any request for clarification which might be put to the relatives would raise questions that better lie latent. Much of this indeterminacy has resulted from the chaos following the swollen shoot disease. Many resident farmers seem indifferent to the fact that the farm they are in charge of is registered in the name of (say) an absent brother.... The more sophisticate farmer may try to justify the fact that it is he who is replanting the farm by referring to his obligation to his brother, while those who are not trying to rationalize their behaviour will casually convey the casualness of the situation'.

While Hill (1963) postulated that the swollen shoot disease might result in the transfer of ownerships and emergence of full individual rights, the actual outcome has been the consolidation of a system of sharecropping among relatives, between the inheritors of land and more distant and junior relatives with less claims on the land. This became more pronounced in the Eastern Region as wealthy farmers began to shift towards investments in land in the Western Region. Currently sharecropping between relatives is quite common within the Suhum-Ayensuano area. Labour has also become scarce, as labourers have also moved to the new frontier areas in Ghana and Côte d'Ivoire, where they can get better remuneration for less work.

With the attainment of independence new opportunities were created for urban employment. Given its very close proximity to Accra, many people from Suhum-Ayensuano also migrated to Accra. Many of the wealthier cocoa farmers also invested in the education of their children, which resulted in the rise of a professional class with landed cocoa interests. The large-scale farmers migrating into new frontier cocoa areas or converting into trade and professional employments continued to retain their land, which they gained an income from by sharecropping with poorer relatives or non-related farmers. This rise in urban 
landed interests ('gentlemen [who] don't like to farm') is reflected in some of the extended interviews with sharecropping tenants of urban-based relatives. For instance, Akosua, a woman farmer at Brong Densuso, farmed on land belonging to her matrilineage. The son of her maternal uncle, a businessman who resides abroad, inherited the land. He had contracted it out to her on a half share (abunu) arrangement. She was responsible for meeting all the costs of farming and hiring of labour.

In other circumstances sharecropping emerges as more of a reciprocal relationship between farmers with land but insufficient capital or labour to rehabilitate old plantations, and farmers with labour and sometimes capital but insufficient land of their own. This is often a relationship between older farmers who are no longer strong enough to farm and younger relatives without land or capital, but with sufficient strength to maintain a cocoa farm. For instance, in an interview at Ayisaa, Govina Wilson narrated:

'My father started the farm many years ago. I took charge of the farm about six years ago. But before that I was helping my father on the farm when I was young... I had to replace some of the trees and these ones are now growing.... I share with my father. He is old now and it was as a result of his hard work that I came to be farming on the land. So, I give him a larger portion of my share so he can take care of himself'.

While this farmer did not specify an exact sharing arrangement, others did in their interviews. Kwame Sakyi, at Bokoekrom, Suhum-Ayensuano, who works a 1.2ha cocoa farm owned by his sister-in-law explained, 'We have an abusa sharecrop arrangement where I take two parts of the money from selling the cocoa and she gets one third. She used to farm the land but because of old age she can't anymore'.

Smallholder farmers often invest in cocoa farms to provide for them in their old age, with the intention of releasing it to a younger person on a sharecrop arrangement. For example, Amos Larbi, with half a hectare of cocoa at Bekoekrom stated: 'My father told me that if you are farming cocoa, when you grow old and cannot work, you could give the farm to someone to work on it so you get something to eat. It is a good investment'.

Some of these types of arrangements operate in a grey zone between sharecropping tenants who replant a cocoa farm and sharecrop labourers who work on previously established plantations. Sharecrop relations can change over time as cocoa plantations age. Sometimes a farmer is provided with a farm to take care of in exchange for a third share. When the farm ages the caretaker may engage in the replanting, in which case the arrangements are renegotiated, and the sharecropper now receives half of the proceeds. For example, Kofi Amankwa narrated:

'When I heard that my grandmother's relatives were here at Ayisaa, I decided to go to them. When I got to Ayisaa, I realised my uncle had made a farm there. So, I decided to stay and I started working on his farm... In the beginning, when I started working, there was cocoa on the land and the arrangement was abusa...In the third year of my service, the cocoa trees were cut down because of akate [capsid insect pests] on the farms. From that time, my uncle told me to take the land and plant it with cocoa so that we will share it equally. We entered into a new arrangement where we stopped abusa and now do abunu. With the new arrangement, I became the sole manager of the farm'.

Sharecropping is also common among the children of men in matrilineal lineages, where fathers without sufficient land of their own seek to gain sharecropping contracts for their sons with the landholding elders of their lineage. The land may be passed on to the children of sons on favourable terms such as a third share going to the lineage rather than the half. In these instances a maternal nephew or brother of the original cocoa farmer inherits the land (Amanor, 2010).

Among close family members, the share given to the owner of the land or the head of the lineage may not necessarily be directly specified. For instance, Felicia Oppong has a 1.2ha cocoa plantation at Bekoekrom, which she inherited from her deceased father. Every year she provides her father's junior brothers with accounts and a share of the proceeds. However, there is no formal arrangement defining how the yield is to be shared:

'I account for the yields to my fathers' junior brothers and they take some of the proceeds or money and I also take some. What I give to them is to be used to take care of the family house. There is no clear-cut arrangement. It is a father-daughter relationship so we did not come to any form of agreement on the terms to share the proceeds of the land. All I can say is that, I give them some of the proceeds, which they use to take care of the house and I also use the rest for my family'.

Similarly, Jonathan Ntow, who is 25 years old, works on 1.2ha of the family land of his mother. Recently the family head has requested that 'he brings something' to support the family house. This rise of sharecropping and sharing on family land is indicative of the increasing shortage of land and that it cannot support all family members. Those who gain access 
to family land for cocoa are expected to provide some part of the proceeds to the family head for the upkeep of the family.

Some of these sharecropping relations can be quite complex. Afari Kisiedu presently takes care of his father's 4.8ha cocoa farm and another 1.2ha that belonged to a maternal uncle. His father's land was inherited by one of his father's maternal nephews. The 4.8ha farm is subject to an abusa arrangement, in which he retains 1.6 ha as his own farm and manages the other 3.2 ha for his father's nephew, who resides in the town of Akropong. Most of his father's landowning relatives are urban-based professional workers. Although he is responsible for managing the farm, his father's nephew pays for labourers on the 3.2ha farm. In addition, his mother left a 2.4ha cocoa farm to him and his three siblings. His younger brother looks after this land and after the harvest of cocoa the proceeds are shared equally between the four siblings.

The costs of rehabilitating cocoa have resulted in the rise of sharecrop tenants and a movement from sharecrop caretakers to sharecrop tenants. Farmers who have found it difficult to meet the costs of replanting from their own capital and labour often turn to tenant farmers and junior relatives to carry out this task as part of a sharecrop arrangement. The tenant caretaker usually receives a half of the crop. Similar relations were also recorded in focus group discussions carried out at Juaboso where farmers described the recent rise of sharecrop tenancies resulting from the costs of replanting cocoa. Elderly cocoa farmers with larger farms in the Juaboso area are currently a major source of land for sharecropping, due to their inability to replant dying plantations. In earlier times most sharecroppers were migrants and gained access to forestland through sharecropping arrangements with indigenous chiefs and landowners (Boni, 2005). As uncultivated land becomes increasingly scarce for indigenes many of them are forced to gain access to land through sharecropping on old plantations, and often with elderly family members without the resources to engage in replanting old cocoa.

Sharecropping tenancies mainly arise in four different contexts:

1. In new frontier areas in which land sales of uncultivated forest are active it emerges between landowners without capital, and labour to develop cocoa plantations. The landlords release mature forested land for the tenants to convert into cocoa plantations. After the plantations start bearing cocoa the land is divided between the landowner and the tenant and the tenants share is recognised as their own land, which they can pass on to their heirs. Hill (1956) noted that in the Eastern Region the arrangements from the 1920s involved landlords receiving two thirds of the cocoa plantation and tenants one third. With the decline of forest frontiers this has been transformed into a relationship for replanting old cocoa, in which the land can be shared equally between tenant and landlord. In the Western Region, the sharecrop arrangements has always involved a split of the farm when it starts fruiting, probably because labour became more available than in the early days of cocoa in the Eastern Region.

2. As a relationship between tenants in search of land and landowners with surplus land in which the landowner is interested in gaining rent from the land.

3. As land becomes increasingly scarce, sharecropping emerges between the wealthy and poor sections of lineages with the large landowners releasing land to their poorer relations on sharecropping terms, again with a strong interest in extracting rent from their land.

4. As a more reciprocal relationship between kin in which those unable to replant cocoa or with insufficient labour and capital to manage cocoa production enter into a relationship with close relatives to produce cocoa. This can occur between elderly and young relatives. It can also occur among the children of men in matrilineal lineages, in which the father secures lineage land for the son on a sharecrop arrangement, since the son does not have formal kinship rights to the land.

Sharecropping may occur as an arrangement between a landowner and a tenant to make or replant a cocoa plantation, or as a labour arrangement on an existing cocoa plantation to manage, weed, and harvest the cocoa. However, the distinction between these two arrangements become increasingly blurred as cocoa becomes susceptible to disease and its management involves a regime of replanting old and diseased portions of farms.

Sharecropping is also an important avenue for women to gain access to land. Fourteen per cent of women in the quantitative survey had cocoa plantations gained under sharecropping arrangements compared to 24 per cent of men. At Suhum-Ayensuano, 30 per cent of women acquired sharecropped plots compared to 47 per cent of men, while at Juaboso 4 per cent of women sharecropped compared to 5 per cent of men.

Sharecropping has emerged as the major avenue for land leasing within the cocoa sector, as land becomes an increasingly scarce commodity. It has emerged as 
a way of financing the replanting of old cocoa farms to compensate for increasing costs of production and the need to expend more resources on labour, agrochemicals and fertilisers to maintain productivity (Ruf, 2010). However, sharecropping also enables non-farming absentee landlords to extract agricultural rent from rural people, including their own kin, without necessarily investing in the cost of cocoa replanting.

\subsection{Contemporary pressures on land appropriation and loss of land}

While many farmers are experiencing rising land shortages, access to land is increasingly gained through family redistribution and through sharecropping relations, rather than through outright land purchase. Redistribution within the family often takes place through sharecropping arrangements, which addresses the fact that those who gain access to land gain a privileged access that others may not share, and thus they provide a portion of their surplus profit to maintain redistribution within extended families. However, extended families are also characterised by social differentiation, and in some instances the wealth acquired by previous generations of commercial cocoa farmers has been invested in other sectors, including trade and education, enabling their descendants to move into urban professions. These urban professionals have often retained their control over land, extracting rents from sharecropping with their poorer relatives and with other farmers. In other instances, farmers have been unable to afford the high costs of labour involved in rehabilitating cocoa plantations, and have given it out to sharecrop tenants to develop. High cocoa production costs can result in poorer farmers releasing their land to sharecrop tenants, who are better able to meet these costs, although this often results in low returns for both parties. This can adversely affect women farmers, who experience greater difficulty in gaining access to land, and are often more dependent upon hiring labour.

A focus on promoting land markets, individual property rights, collateral loans for investments in agricultural commercialisation, and the uptake of new hybrid varieties and inputs, is not likely to strengthen the land rights of the poor and of women, who often depend on secondary rights in land allocated through the family (Peters, 2013). This can create further pressures of indebtedness, as farmers who are unable to meet the increasing expenditure on labour and inputs are forced to release their land through sharecropping to others in a better condition to meet these requirements, or family elders select richer members over poorer kin to cultivate family land because they have more capital to invest in inputs.
The development of private land markets and rights can also fuel speculation in land and the expansion of purchases in land by commercial farmers and aspiring urban-based entrepreneurs seeking to invest in agriculture. Land reforms that seek to secure individual property rights and decentralise management of this process to traditional authorities, can empower chiefs to alienate user rights that are not clearly defined, to (urban-based) commercial farmers, and to redefine what constitutes customary property and the evolution of customary practice to modern conditions (Boni, 2005; Amanor, 2008; Yaro, 2012). In the Ayensuano area, during research, several farmers were anxious that the paramount chiefs over the land were negotiating the sale of their land to prospective rubber commercial farmers and finding ways of ejecting them from the land. It is extremely difficult to legislate to protect the land rights of the vulnerable and women, particularly in circumstances in which available family land cannot meet the needs of all family members and family redistribution is subject to a process of selection that may be influenced by economic circumstances and power relations. These cannot be addressed through legally strengthening abstract individual property rights, when the acquisition of these rights by the wealthier segments of society often erodes the user rights of the poor.

In summary, over the last 100 years there has been a significant shift in cocoa production from a process of extensive farming associated with the acquisition of large parcels of land, acquisitions of multiple farms, and acquisition of lands in new forested frontier areas. These large holdings were broken up as the land purchasing cocoa farmers allocated portions to extended kin who had helped them in transferring forest into habited settlements with access to markets and roads. Migrant smallholders were also able to join land-purchasing companies, which collected financial contributions from farmers to purchase large tracts of land, which were subsequently divided among the members. Within local communities, farmers could also establish cocoa by clearing uncultivated forestland with their kinsfolk and claiming it as their own land or on land already cleared and claimed and by their lineage. The opening up of cocoa by large migrant farmers frequently attracted labour to the new frontier areas, which could be subsequently hired by local farmers to create smaller cocoa plantations with more modest capital outlays. In many areas labour was the main constraint preventing the expansion of cocoa farming, until labourers began migrating to the area. As land became scarcer and new frontier land no longer existed, the opportunities to accumulate capital in cocoa became more limited. Land became less available on the market and landowners sought to gain 
rental income from sharecrop contracts rather than land sales, partly to hedge against the rising values of land. Extended families shifted from institutions for transferring land to members willing to work (Hill, 1963), to protecting the landed interests of those at the centre of the family and releasing land to the more distant lines of the family on sharecrop relations. This is evident from the differences in land ownership between the older cocoa lands in Suhum-Ayensuano, where smaller lands and sharecropping are more prevalent, and the more recent cocoa frontiers of Juaboso in which youth and women are able to gain land from their families and women from their husbands. The decline of land access through family members makes it harder for many women to gain access to land for cocoa farming. However, this is only one part of the story, since the ability to participate in cocoa farming has also been influenced by changing ecological relations, the decline of forests and the rise of epidemics in cocoa since the swollen shoot crisis of the 1950s. The cost of replanting and rehabilitating old cocoa farms in declining forest areas has also limited the abilities of farmers to participate in cocoa and resulted in the advent of sharecropping. The next section explores changes in the labour relations and changes brought about by the increasing labour requirements of farming as new frontier areas decline. 
Cocoa production is labour intensive, requiring about four rounds of weeding every year, removal of mistletoes and other epiphytes, shade management through pruning, removal of basal suckers, and then harvesting, opening the pods, fermenting and drying the beans (Dormon et al., 2004). Labour requirements for cocoa production have been estimated at 136 man-days per ha (Bray, 1959), 105 man-days per ha (Urquhart, 1961) and 109 man-days per ha (Beckett, 1944) in forested land. These labour requirements increase as the original vegetation is replaced by secondary bush and grassland, as more invasive weeds move into the forest and as cocoa becomes more vulnerable to diseases. Ruf (2010) estimates that in Côte d'Ivoire the number of days of labour on a hectare of land in the first year of creating a plantation increases from 86 days in primary forest to 168 for replanting.

As a result of these labour requirements hired labour has been central to the development of cocoa production since its inception. Labour is intricately related to the dynamics of frontier settlement, access to land, family relations and the scale of production. The earliest cocoa farmers depended upon both extended family labour and hired labour. Hired labour was largely drawn from migrant labour. The earliest labourers were drawn from people originating from the Accra Plains, Volta Region and Togo. By the 1920s, the dominant migrants originated from northern Ghana and Sahelian countries, including Haute Volta, Mali and Niger - from areas largely designated as labour reserves by colonial authorities, in which people were forced to migrate to meet tax obligations (Hill, 1956; Amanor, 1994; Austin, 2005).

The dominant systems of hired labour in the colonial period included:

1. the nkotokoano system, in which the labourer was remunerated at the end of the season by a fixed payment per bag of cocoa harvested;

2. the annual labour system;

3. the abusa caretaker/labourer system;

4. casual labour, hired on a daily rate (Hill 1956, 1963; Austin, 2005).
The abusa caretaker sharecropping system was a later innovation than monetary contracts (Austin, 2005). Sharecropping emerged as cocoa planters established their early farms and acquired new lands. The established farms were given out to labourers on a third share and family labour was used to open up new farming areas and establish new plantations. During the expansionary stage of cocoa from the 1920s to 1960s, sharecropping labour was common in the older frontier areas on mature plantations, while extended family labour prevailed in the new frontier areas (Hill 1956, 1963; Amanor, 2010). Austin (2005, p. 319) provides detailed instances of this type of arrangement: 'Kwaku Gyekyi and Kojo Bah's practice was to use wage labourers to supplement their own and their conjugal families' energies in making new cocoa farms; then hand them over to abusa caretakers when the trees started yielding'.

Austin (2005) argues that in Asante, sharecropping replaced monetary contracts as a result of the price volatility of cocoa, and the failure of cocoa farmers to honour the annual payments due to labourers. In this context the labourers began to demand a transformation of annual payments into a share of the proceeds of the harvest.

Annual and abusa labourers were mainly employed on established cocoa plantations. However, when these plantations became old and in need of rehabilitation the labour often migrated to newer frontier areas, where remuneration was often better and labour less intense, resulting in labour shortages (Amanor, 2010). By the 1970s, the structure of labour within the cocoa sector in Ghana was transformed. The rapid expansion of the cocoa industry in neighbouring Côte d'Ivoire resulted in surplus world production and declining international prices. Since the cost of production in Côte d'Ivoire was significantly lower than in the old frontier areas in Ghana, labour was more attractively remunerated. Consequently, Sahelian migrant labour relocated from Ghana to the Côte d'Ivoire. Farm labour within the Ghanaian cocoa sector became increasingly scarce and shifted largely to casual labour by local youth (Amanor, 2010). The high costs 
of rehabilitating old plantation also made the abusa caretaker system increasingly redundant, since it was adapted to established plantations in forested areas, and the costs of replanting cocoa in secondary fallow was much higher than in mature forest. Thus, in old, rehabilitated frontier districts abusa labourers were often replaced by wage labour, and when the farmer could not afford wage labour, they contracted out the land to a sharecrop tenant to manage the process of rehabilitating old plantations.

\subsection{Contemporary labour relations in Suhum-Ayensuano and Juaboso}

Seventy-three per cent of farmers interviewed in the two areas hired labour on their cocoa farms. Eighty-one per cent of farmers within the Suhum-Ayensuano area hired labour, compared to 65 per cent at Juaboso. In both settlements more women hired labour than men. Seventy-five per cent of women hired labour compared to 71 per cent of men. In the Suhum-Ayensuano area, 84 per cent of women hired labour compared to 80 per cent of men and at Juaboso, 68 per cent of women compared to 63 per cent of men.

Farmers in Suhum-Ayensuano were more likely to engage in sharecropping than at Juaboso, but they also depended more upon hired labour despite having smaller farms than those found at Juaboso. This suggests that farmers at Juaboso are more able to meet their labour requirements by mobilising existing family labour, rather than depending upon hired labour.

In the context of the different tasks carried out on farms, the most significant difference in the two areas was in the use of hired labour for land clearance. Only 15 per cent of farmers at Juaboso hired labour for farm clearance, compared to 48 per cent at SuhumAyensuano (see Table 5.1). This seems to relate to the different dynamics of frontier development within the two areas. Replanting has become a recurrent event for decades in the Suhum-Ayensuano area but is more recent in Juaboso. At Juaboso, farmers were able to mobilise neighbouring kin to help in the clearing of land, while at Suhum-Ayensuano the fragmentation of the family, resulting from movements to new frontier areas and the increasing transformation of family land into sharecrop tenures, constrains the mobilisation of family members for farm work. Thus, the use of labour is connected with dynamics of frontier settlement and the role of family labour in cocoa cultivation.

In a focus group discussion with male farmers at Juaboso-Nkwanta, one participant recounted the various labour requirements in managing cocoa, but also the importance of family labour in creating cocoa farms:

'When one acquires land for cocoa, you need to cut trees, clear undergrowth, and burn it. After which you plant cocoyam, plantain and other food crops, which is then intercropped with the cocoa seedlings to provide shade.... Without a thorough regime of weeding the farm - at least four times annually - the cocoa will not grow well. After this, husbands with or without the help of labourers clear the forestland. Their wives normally plant the food crops, while the men plant the cocoa. If he has two wives, he will make boundaries on the farm to indicate the area that each wife and her children will control. When the trees grow, we need to prune, spray and weed under them. During the harvest season...you need harvesters, carriers, breakers and dryers. You can use a combination of family labour, casual by-day labour, abusa caretaker, annual labour caretaker, abunu sharecropper, and work parties to carry out these tasks'.

Another participant captured the changing nature of labour as the farm ages:

'In the past we worked our farms with our wives and children. But now labourers are gradually replacing or complementing family labour. We have by-day workers and some labourers who work per acre and they are paid accordingly. Other farmers also hire labourers who will work on the land for a year and they are paid a fixed

Table 5.1. Percentage of men and women farmers using hired labour

\begin{tabular}{|l|c|c|c|c|c|c|c|c|c|c|}
\hline Type of labour & \multicolumn{3}{|l|}{ Suhum-Ayensuano (\%) } & \multicolumn{3}{|l|}{ Juaboso (\%) } & \multicolumn{3}{l|}{ Total sample (\%) } & $\begin{array}{l}\text { Total no. } \\
\text { of farmers }\end{array}$ \\
\hline & Male & Female & Total & Male & Female & Total & Male & Female & Total & \\
\hline Land clearance & 47.6 & 49.4 & 48.1 & 12.8 & 19.2 & 15.2 & 29.8 & 32.0 & 30.6 & 517 \\
\hline Weeding & 76.2 & 80.5 & 77.6 & 58.7 & 65.4 & 61.2 & 67.3 & 71.8 & 68.9 & 517 \\
\hline Pruning & 42.7 & 48.4 & 44.8 & 38.4 & 44.2 & 40.6 & 40.5 & 46.4 & 42.6 & 517 \\
\hline Harvesting & 66.5 & 72.7 & 68.5 & 48.8 & 50 & 49.3 & 57.4 & 59.7 & 58.2 & 517 \\
\hline No. of farmers & 164 & 77 & 241 & 172 & 104 & 276 & 336 & 181 & 517 & \\
\hline
\end{tabular}

Source: Authors' own 
rate and provided with some other welfare arrangements. Those who work for a year are fully catered for in terms of feeding, health, inputs, accommodation - as if they belong to your household (adopted labourers) - but they still receive a payment at the end of the year as agreed. Many of these labourers are young migrant men and children mostly from the North. This arrangement was in existence before this community was established, but it is becoming difficult to find labourers now unlike in the past'.

In contrast, family labour was much less significant on farms in the Suhum-Ayensuano districts. The family lands have become highly fragmented and situated in different settlements. They are usually allocated to one of a number of siblings or given out on sharecrop tenancies. Siblings are often located in different settlements, working on different plots of land. As a result, it is difficult to mobilise extended family labour and farmers rely more on casual hired daily labour.

\subsection{Familly labour}

Most of the cocoa farms at Juaboso continue to be worked with family labour. The largest male farmers often have plots in different areas, which they allocate to different wives to weed and manage with their children after they have cleared and planted the land with cocoa. These farmers control the income from these cocoa plantations after harvest, part of which they redistributed to their wives and children. The main incentive for their wives and children is future inheritance of the land they work. Similar arrangements have existed in the Suhum-Ayensuano area in the past (Hill, 1963), but these types of arrangements are no longer common, since farmers do not have sufficient land to allocate to wives or children. As has been discussed above, family land is often allocated to a select group of lineage members, who often share their crop with the lineage elders, or are allocated it on a sharecrop arrangement. Most families do not have sufficient land to allocate to all their children. As a result, kin are highly mobile and spread out through many different settlements or have moved into other livelihoods. It is therefore not common for farmers to rely on close kin, or even on their own children for help in farm labour. The scarcity of land often results in sharecropping relations replacing family farming, and co-operation between close family kin being expressed through sharecropping arrangements and variants on sharecropping, which, as we have seen, can even extend to parents and children.

In contrast, in Juaboso farmers continue to mobilise extended family labour in farm work to which they add casual labour, if they have the financial resources. As one 27-year-old cocoa farmer at Abrokofe stated: 'I do not usually hire labour because most of the time, my siblings and even my mother help in farming activities. It is only when I am going to weed that I usually hire about two labourers'.

However, many farmers cannot afford to hire labour. As one 49-year-old farmer at Juaboso Nkwanta commented:

'I don't have money to hire labourers so I do the work myself. I do the work with my wife because my children are too young to assist. I hire labourers when I have some money, but it is rare'.

Family labour is more prevalent at Juaboso than Suhum-Ayensuano, but it is also declining as land becomes scarcer and farm production more commodified. Recent child labour and education policies and laws are eroding the use of young labour on farms. As a consequence, many young people are growing up without the experience of farm work and turning to other livelihoods. Farmers are becoming less reliant on child labour. Some farmers are turning to sharecropping arra+ngements to replace family labour. As a young man at Juaboso Nkwanta stated: 'Some parents are so old and cannot even work on the farm but they will not give their cocoa farms to their children to manage, but rather a total stranger will get the farm as a caretaker'.

\subsection{Hired labour}

Four distinct forms of hired labour exist in the two districts: daily labour, contract labour, abusa and annual labour. The first two are allocated to specific farm tasks over a short period of time, while the latter two are concerned with the management of the whole cocoa plantation over a period of a whole farm season or more. Local youth and small farmers seeking to supplement their farm incomes provide most of the casual labour. In Juaboso there is also a significant sector of migrant labourers from Togo and northern Ghana. Although migrant labour was significant in Suhum-Ayensuano in the colonial economy it has declined as the cocoa frontier moved westwards, and the main labourers are now local.

The two dominant forms of task specific labour are the by-day and the contract labour system (adopaa). The by-day system involves payment to a labourer hired on a daily basis to form a specific task. The labourer usually works from $8 \mathrm{am}$ to $12 \mathrm{pm}$. The adopaa system is used for weeding a specific area of the farm and for pruning cocoa trees. In the Suhum-Ayensuano area, weeding contracts are usually negotiated for small 
areas of farm measured by 'ropes' (ahoma) consisting of a number of arm spans - which may be 10 by 10 or 15 by 15 . In Juaboso, the adopaa system has also been adapted to scarcity of credit among farmers with migrant labourer gangs from Togo working in advance of payment after the cocoa harvest. For example, one male focus group participant stated:

'Usually when these labourers come, they work on multiple farms and write the names of the farmers and amount owed them down. So, when it is harvesting time, they come back to the communities and go to these farmers to collect their monies. Usually, they measure the farm by the acre and charge you accordingly. If they are weeding the cocoa farm, they charge about GHC100 per acre. ${ }^{5}$ If it is a food crops farm, they may charge between GH\$50-80. Sometimes, you can negotiate with them and they will take GHC50 for weeding the food farm. When the harvesting season is in, then they come back for their money. Even yesterday we made a public announcement that those who came to do the credit labour have come back to the community, so those who owe them should pay them'.

A 52-year-old male cocoa farmer interviewed at Abrokofe narrated:

I go for the long-term labourer (adopaa) because you can pay them on credit. As for the by-day they charge for the day and you have to pay at the end of the day but the long-term labourer will take the money after you harvest - and they weed, cut mistletoe and do other things you require.

The annual labourers and abusa caretakers are responsible for looking after established cocoa plantations. They perform all the farm tasks, including weeding, pruning and harvesting. The annual labourer is remunerated after harvest with a pre-agreed amount, while the abusa caretaker receives a third of the harvest. The landlord is responsible for the purchase of inputs. However, the abusa caretakers may choose to hire additional labour at their own cost. As outlined by a farmer in a focus group discussion at Abrokofe, the work of an abusa caretaker includes the following:

weeding three times a year, cutting of mistletoe two times a year, and if he knows how to spray and you have the machine then he will spray while his wife fetches the water. If he hires someone to do the spraying, he will have to bear the cost. If the farm owner doesn't have the machine, then hiring the machine becomes his expense. But even if you have the machine and the caretaker doesn't know how to use it then you the farm owner can do the spraying to prevent the destruction of the machine.

In Juaboso most of the annual labourers and caretakers originate from northern Ghana. They are mainly employed by the larger cocoa farmers. Most smallholders using daily or contract labour to supplement their household labour. While annual labourers and abusa caretakers were common in the Suhum-Ayensuano area in the colonial days, they have largely disappeared. The fragmentation of farms results in most Suhum-Ayensuano farmers using casual daily or contract labour rather than annual or abusa labourers. In Suhum-Ayensuano, replanting of cocoa has resulted in the replacement of abusa caretakers by abunu tenants, who bear the costs of replanting of cocoa. The abusa caretaker system is only cost effective on larger plantations, where the costs of hiring large amounts of daily labour are deemed to be a significant drain on the financial reserves of farmers. In the Suhum-Ayensuano area the high costs involved in replanting cocoa, results in many farmers seeking to lease out their land under the abunu sharecropping tenant system, when they have difficulty in meeting these costs.

Labour has been a major constraint in cocoa farming from its inception. In many areas the uptake of cocoa among local farmers was dependent upon migrant farmers laying the foundations for the migrants of labourers to the area, which then enabled local farmers to establish their own plantations. The pioneer cocoa farmers of the late nineteenth century initially drew upon large networks of family dependent labour, with distant origins in domestic slave labour recruited into the early nineteenth century oil palm industry (Amanor, 1994; Hill, 1963; Johnson, 1964; Austin, 2005). Austin (2005) also records that domestic slavery and pawns (family members taken as security against a loan, who provide interest in labour until repayment of the debt) were important in the early years of the development of the Ashanti cocoa industry (Austin, 2005). By the early twentieth century pawnage became replaced by pledging of cocoa farms against debt (Austin, 2005). Colonial rule and its taxation schemes created new opportunities for the hiring of labour; large number of migrants from Burkina Faso (then Upper Volta), Niger, and Mali moved into Ghana to work in the cocoa sector to gain cash incomes. They usually worked as annual or abusa labourers. Large cocoa farmers took advantage of this large source of labour to complement extended family labour, employing migrants on already 
established cocoa plantations as caretakers while using family labour to clear new frontier areas that were converted into cocoa farms (Hill, 1956). Women often played an important role in this, cultivating the food crops among the cocoa seedlings. Plantain was an important crop cultivated by women that also provided shade to nurse young cocoa seedlings. However, as the cocoa began to form a canopy, food crops could no longer be cultivated, and as cocoa became the predominant crop within old frontiers there was less scope for women and other family members to gain livelihoods from food crop farming. By the 1950s and 1960s labour relations began to change within cocoa; rehabilitation and replanting of cocoa in secondary bush became dominant in old pioneer areas. Since labour in old plantation areas was more arduous and farmers in these areas had less disposable income (resulting from declining yields, mounting disease, and weed problems) migrant labour began to relocate to new frontier areas where they received more favourable forms of remuneration. By the 1970s, this became critical as the cocoa frontier in Ghana declined and cocoa cultivation in the new frontier areas of Côte d'Ivoire gathered momentum. Migrants from neighbouring sahelian countries relocated from Ghana to Côte d'Ivoire, which now replaced Ghana as the leading global cocoa producers. As a result, cocoa farmers in Ghana could no longer rely on a supply of cheap migrant labour.

The combination of declining access to migrant labour and declining ability to provide family land for children has reshaped labour relations within cocoa. With a lack of access to family land a significant proportion of youth shifted from working on lineage land to working as labourers. They moved to newer frontier areas where they hoped to save money from labouring to purchase their own land or gain sharecrop contracts. With the retraction of youth labour from the family, established cocoa farmers have become more dependent upon hired labour than before. This labour is now largely provided by youth and farmers with insufficient land to meet their needs for an income, since most of the migrant labourers have left old frontier areas. This has resulted in a shift from long-term labour contracts (such as annual labourers and abusa labourers) to short-term casual day-labour and contract labour. Labour has become more expensive. The increased costs of labour and of rehabilitating old unproductive plantations has created huge expenditure pressures; many cocoa farmers sharecrop their land because they lack the labour or capital to hire labour to successfully maintain cocoa. In many areas of the Eastern Region and Ashanti, farmers have shifted out of cocoa into other crops. For instance, in the Asesewa area of the Eastern Region as early as the 1950s, farmers replaced cocoa with maize, taking advantage of the proximity of Accra to become a major supplier of urban food. In the 1970s, many farmers in the Kwae area of the Eastern Region converted to modern hybrid oil palm production, which was promoted by government services including outgrower schemes. Within areas that retain cocoa as a major crop, these shifts in the cost of labour have resulted in smaller cocoa farms, more allocations of land to sharecrop tenants, and increased expenditure on labour. This creates larger barriers of entry into cocoa production, resulting in its domination by more mature and elderly farmers with a large number of younger farmers transformed into labourers. This also marginalises women who increasingly find the high costs of labour an entry barrier to production. Women have less opportunity to mobilise family labour as compared with senior men. This leaner, more capital-intensive cocoa sector favours the male elders at the centre of family lands who can use their influence over family affairs and control of land to make demands on family labour. These trends appear to be more pronounced in older frontier areas. Thus, in the older frontier areas of Suhum, farms are both smaller and use more hired labour, reflecting the declining role of family land and family cooperation in production. In the more recent frontiers of Juaboso, where family land is still significant, male youth play a larger role in family production and cocoa farmers are less dependent upon hired labour. 
In contrast with the widespread usage of hired labour by cocoa farmers, significantly fewer farmers purchase inputs and seeds. There is a wide disparity between the recommendations and visions of the cocoa industry and science and technology sectors of farmers achieving high yield through planting hybrid seeds and using inputs, and the actual practices of most farmers. Existing studies provide a very mixed picture of uptake of inputs and hybrid seeds by farmers. These findings are complicated by the disbursement of free inputs and seedlings by government agencies and private corporations and mass spraying campaigns by government agencies, which can result in the appearance of increasing use of inputs by farmers.

Hainmueller, Hiscox, and Tampec (2011) suggest that 21 per cent of farmers applied fertilisers and 37 per cent used agrochemicals. There were significant regional variations in this survey. For instance, in the Eastern Region, only 9 per cent of farmers used fertilisers. In a survey of Eastern, Ashanti and Western Regions, Bymolt, Laven, and Tyszler (2018) suggest that 39 per cent of farmers used applications of granular fertiliser, 53 per cent liquid fertiliser, 88 per cent pesticides, 74 per cent fungicides and 51 per cent herbicides. In contrast, drawing on the Ghana Cocoa Farmers Survey which has been carried out over a number of years, Kolavalli and Vigneri (2017) suggest a significant expansion in the use of inputs: with fertilisers usage growing from 9 per cent in 2001/2 to 57 per cent in 2009/10; and the use of agrochemicals expanding from 50 per cent in 2001/2 to 90 per cent in 2010. Ruf and Bini (2011) also suggest that 75 per cent of cocoa farmers in Ghana use fertilisers compared to only 15 per cent in Côte d'Ivoire, and that this has resulted in much higher yields in Ghana than Côte d'Ivoire. In marked contrast, an International Institute of Tropical Agriculture survey of Ghanaian and Ivorian cocoa farmers carried out in 2009 reported that only 17 per cent of Ghanaian and 13 per cent of Ivorian farmers used fertilisers (Gockowski and Sonwa, 2011).

Kolavalli and Vigneri (2017) propose that the marked uptake in new technologies has resulted in a distinct pattern of social differentiation, in which those using low technology gain outputs of $400 \mathrm{~kg} / \mathrm{ha}$, those using some inputs gaining between 400 to $800 \mathrm{~kg} / \mathrm{ha}$, and those using high inputs (industry recommendations) gaining from 800 to $1,500 \mathrm{~kg} / \mathrm{ha}$. They suggest that those in the lowest category have declined from 85 per cent of farmers in 2001 to 65 per cent in 2010, and those in the medium category have increased from 12 per cent in 2001 to 38 per cent in 2010, and those in the high yield category from 2 per cent in 2001 to 9 per cent in 2010. They paint a picture of technologyinduced change gradually but significantly lifting cocoa farmers out of poverty. However, these are questionable assertions given the variance in existing data. Ruf and Bini (2011) also caution that wide variations in yields are found among farmers using hybrids and modern cultivation techniques in different areas. While yields of $4,000 \mathrm{~kg} / \mathrm{ha}$ were found in newly cleared cocoa forests (where higher yields are to be expected) in the Nzema area, these dropped to around 1,000kg/ha in old cocoa plantations in Ashanti.

Upbeat assessments of a significant uptake of technology and major gains in yields are also at variance with concerns with the increasing impoverishment of farmers and the need to facilitate the uptake of new technology or exit from cocoa. Odijie (2018) reports that when the government of Ghana withdrew its support for the free spraying of cocoa farms in 2014, yields dropped by 18 per cent, forcing the government to reintroduce mass spraying. Odijie (2018) has argued that government subsidisation of cocoa has not significantly benefitted cocoa farmers in Ghana, but rather led to increased impoverishment as world cocoa prices decline.

\subsection{Use of inputs at Suhum-Ayensuano and Juaboso}

Quantitative data collected in our two research sites, shows that while farmers widely claim to use modern hybrid varieties, few of them are able to adhere to the recommended management practices for input use, particularly in the use of fertilisers that are critical for achieving higher yields. Only 16 per cent of farmers used fertilisers, and this was often sporadic rather than consistent. In Juaboso, only 9 per cent of farmers used fertilisers compared to 25 per cent of interviewed farmers in Suhum-Ayensuano. However, many of the Suhum-Ayensuano farmers only used fertilisers when 
freely distributed; only 16 per cent of Suhum-Ayensuano farmers purchased fertilisers. In contrast with the low use of fertilisers, agrochemicals are widely used, with 89 per cent of all farmers using agrochemicals on their farms and 83 per cent purchasing them on the market. There are significant regional differences with only 67 per cent of Suhum-Ayensuano farmers purchasing agrochemicals compared to 97 per cent of Juaboso farmers (see Table 6.1).

More farmers at Suhum-Ayensuano use fertilisers than at Juaboso, and more farmers at Juaboso use agrochemicals than those at Suhum-Ayensuano. The reasons for differences between Suhum-Ayensuano and Juaboso are most likely to be complex. In relation to fertilisers this is most obviously (in part) related to perceptions of soil fertility. Eighteen per cent of farmers interviewed at Suhum-Ayensuano considered their soils to be very poor compared to 1.4 per cent of farmers at Juaboso. Concerns of poor depleted soils were also reflected in the in-depth interviews at Suhum-Ayensuano. For example, Ofosu Asamoah, a cocoa farmer interviewed at Brong Densuso (SuhumAyensuano) commented:

'The land's fertility has declined since we got it from our fathers. But with the help of the fertilisers the soil is regaining its strength... If not for the fertiliser the land would be as infertile as it was during our fathers' time. The land was dead when we got it from our fathers'.
Some farmers at Suhum-Ayensuano use fertilisers sporadically to address soil fertility issues rather than to specifically increase the yield of cocoa. For instance, Afari Kisiedu applies fertiliser every three years to address soil exhaustion. Others apply them when freely distributed by government but are reluctant to use their own scarce capital to make purchases. However, not all farmers at Suhum-Ayensuano suffer from poor soil fertility: 38 per cent of the interviewed farmers consider their soils to be highly fertile compared to 19 per cent of farmers at Juaboso. This is not surprising since the soils of the dry semi-deciduous forest zone in which Suhum-Ayensuano lies tend to be more naturally fertile and more suitable for cocoa cultivation than the more acidic soils of the moister forest zone around Juaboso (Hall and Swaine, 1981). In contrast, cocoa diseases at Juaboso are of much larger concern to farmers than soil fertility. This results in priority given to agrochemicals, since these are critical in maintaining yields in infested cocoa. Therefore, it is likely that widespread scarcity of capital and critical conditions of production will force the majority of farmers to make choices on where to allocate expenditure, rather than to follow extension recommendations. These differences are likely related to the maturity of cocoa on farms, and the stage of replanting of new farms (older farms are more likely to be vulnerable to disease), and the types of cocoa varieties being planted and their resistance to pests and diseases.

While a large number of farmers in both localities plant hybrid varieties, these are often combined with older

Table 6.1. Percentage of farmers using or purchasing inputs in Suhum and Juaboso

\begin{tabular}{|c|c|c|c|c|c|}
\hline & District & Male (\%) & $\begin{array}{l}\text { Female } \\
(\%)\end{array}$ & $\begin{array}{l}\text { Total } \\
(\%)\end{array}$ & $\begin{array}{l}\text { No. of } \\
\text { farmers }\end{array}$ \\
\hline \multirow[t]{3}{*}{ Purchase of fertilisers } & Suhum-Ayensuano & 17.7 & 11.7 & 15.8 & 241 \\
\hline & Juaboso & 7.0 & 10.6 & 8.3 & 276 \\
\hline & Total & 12.2 & 11 & 11.8 & 517 \\
\hline \multirow[t]{3}{*}{ Use of fertilisers } & Suhum-Ayensuano & 29.9 & 14.3 & 24.9 & 241 \\
\hline & Juaboso & 7.6 & 11.5 & 9.1 & 276 \\
\hline & Total & 18.5 & 12.7 & 16.4 & 517 \\
\hline \multirow[t]{3}{*}{ Purchase of agrochemicals } & Suhum-Ayensuano & 70.7 & 59.7 & 67.2 & 241 \\
\hline & Juaboso & 97.1 & 94.2 & 96.0 & 276 \\
\hline & Total & 84.2 & 79.6 & 82.6 & 517 \\
\hline \multirow[t]{3}{*}{ Use of agrochemicals } & Suhum-Ayensuano & 81.7 & 75.3 & 79.7 & 241 \\
\hline & Juaboso & 97.7 & 96.2 & 97.1 & 276 \\
\hline & Total & 89.9 & 87.3 & 89.0 & 517 \\
\hline \multirow[t]{3}{*}{ Use of modern hybrids } & Suhum-Ayensuano & 43.9 & 35.1 & 41.1 & 241 \\
\hline & Juaboso & 93.6 & 97.1 & 94.9 & 276 \\
\hline & Total & 69.3 & 70.7 & 69.8 & 517 \\
\hline
\end{tabular}

Source: Authors' own 
varieties selected by farmers from trees on their farms. Three main varieties are planted by farmers: modern hybrids, Amazonia hybrids, and Amelonado (see Figure 6.1). The Amelonado varieties (also popularly known as Tetteh Quashie) are the original South American varieties introduced to the Gold Coast in the nineteenth century. The Amazonia hybrids are the first generation of hybrids widely distributed during the 1970s. These hybrids are no longer produced by government services; they have been indigenised by farmers, mixed up with older planting materials and reselected by farmers for promising traits. ${ }^{6}$ These are mixed with older Amelonado varieties, with some farmers classifying these mixes as Amazonia and others as Amelonado. The modern hybrids are the new generation of fast-maturing high-yielding varieties that require large applications of fertilisers and management with agrochemicals to achieve high yields. The new hybrid varieties have been widely planted by farmers, since they are frequently freely distributed by extension services and provided with other free inputs in a package as incentives to replace older cocoa. Within the quantitative survey, 65 per cent of farmers planted modern hybrids, compared to 30 per cent planting Amazonia. Around 5 per cent planted Amelonadoderived seeds. There is a significant variation in the uptake of modern hybrids within the two research areas, with 92 per cent of farmers within Juaboso planting modern hybrids, compared to only 30 per cent at Suhum-Ayensuano. The majority of farmers (58 per cent) at Suhum-Ayensuano planted Amazonia varieties, which they selected from trees on the farms. However, over 60 per cent of farmers in the survey selected the cocoa that they plant from seeds on trees (see Table 6.2). Less than 30 per cent of farmers planted certified hybrid seeds or seedlings. Many farmers are planting

Figure 6.1 Cocoa varieties planted on cocoa farms in Suhum Ayensuano and Juaboso (Percentage of farm plots)

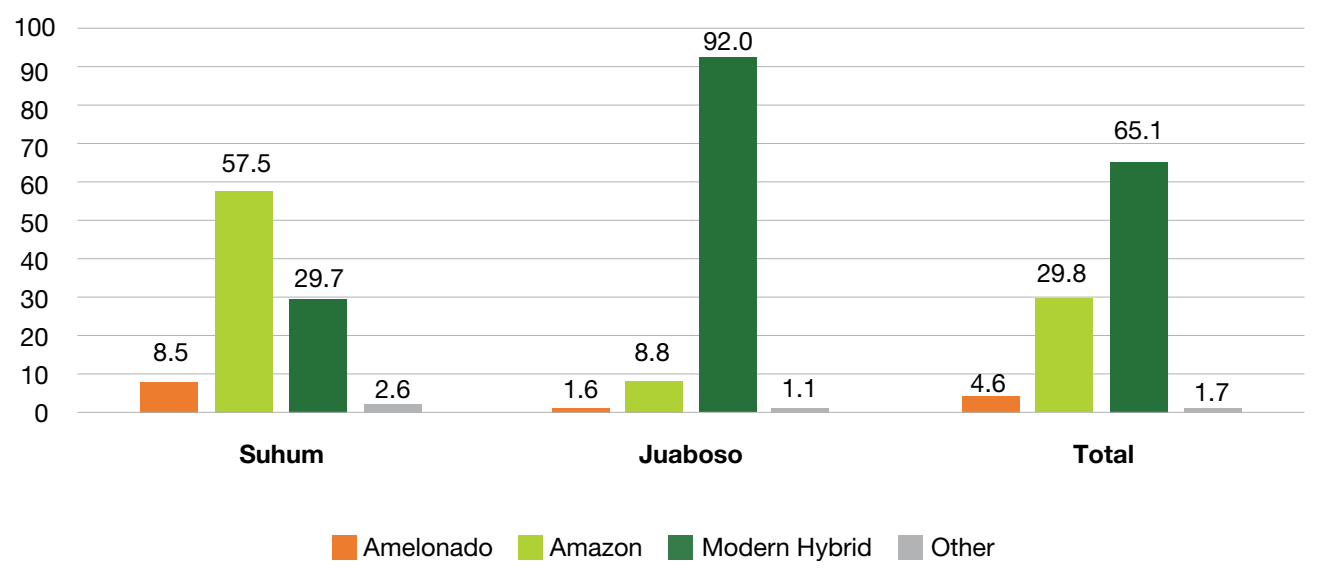

Source: Authors' own

Table 6.2. The sources of cocoa planting materials in Suhum Ayensuano and Juaboso

\begin{tabular}{|c|c|c|c|c|}
\hline Seeds source & $\begin{array}{l}\text { Suhum-Ayensuano } \\
(\%)\end{array}$ & Juaboso (\%) & Total (\%) & T-test P value \\
\hline Selected from trees around & 55.4 & 65.9 & 61.4 & 0.0008 \\
\hline Provided by extension services & 16.0 & 38.2 & 28.7 & 0.0000 \\
\hline From NGOS & 0.0 & 0.0 & 0.0 & - \\
\hline From Farmer association/coop & 6.8 & 5.2 & 5.9 & 0.2737 \\
\hline Purchased from private dealer & 12.3 & 7.3 & 9.5 & 0.0086 \\
\hline \multicolumn{5}{|l|}{ Planting method: } \\
\hline Planted from seeds & 55.4 & 82.3 & 70.7 & 0.0000 \\
\hline Seedlings & 22.9 & 21.4 & 22.1 & 0.5877 \\
\hline $\begin{array}{l}\text { Nursed seedlings before } \\
\text { planting }\end{array}$ & 10.4 & 18 & 14.7 & 0.0008 \\
\hline
\end{tabular}

Source: Authors' own

6 It is likely that some farmers characterise these mixes as Amelonado and others as Amazonia. 
hybrids from seeds selected from trees (which will not breed true) rather from certified seeds and seedlings.

Many farmers expressed some reservations about the performance of the new hybrid varieties on their farms. The hybrids are generally regarded as maturing faster and yielding heavy early crops than the older varieties (in Juaboso they are commonly called abrewa bedi, meaning that the old lady will eat (profit), and in Suhum-Ayensuano akukra bedi - the old man will eat, meaning they yield rapidly so old people can afford to invest in them and gain a profit before they die). Some farmers regard the hybrid varieties as yielding better than the older varieties. For example, during an interview , a farmer at Abrokofe in Juaboso said, 'The hybrid variety bears more fruit than Tetteh Quashie'. Other farmers at Suhum-Ayensuano regard the hybrids of having smaller seeds which provide less weight when bagged. While the hybrids may yield more in earlier years, they are commonly considered to be less robust than the older varieties, and more vulnerable to pests and diseases. A familiar theme among farmers was the susceptibility of hybrids to diseases. For example, when interviewed one 52-yearold female cocoa farmer from Abrokofe said:

'When our parents were cultivating the local breed, we didn't know of all these diseases that are affecting and destroying our cocoa farms now. I think the hybrid variety came with these various cocoa diseases we are suffering from today'.

A second common theme is the short life span of hybrid varieties and their vulnerability. For instance, Solomon Okine, a farmer interviewed at Brong Densuso, stated:

'I have two acres [0.8ha] of Amazonia and two acres of hybrid. The Amazonia is longer lasting than the hybrid. Amazonian can stay and produce fruits for more that 60 years. Hybrid on the other hand can last up to about 25 years. Some of the farmers are trying to get back to the Amazonia. They give us the hybrids because they claim the hybrid produces a faster yield. But with the hybrid, you have to be constantly giving it fertiliser. It takes about two and a half years or sometimes three years to blossom and produce fruits. The Amazonia on the other hand takes about three and a half years. So, there is almost a year interval between them in terms of their ability to producing fruits'.

While farmers are not convinced about the advantages of hybrid cocoa, they also regard themselves as having skills in selecting promising cocoa plants that adapt well to their farm environment, a point that is largely dismissed in current approaches to the uptake of cocoa technology. According to Ofosu Asamoah a farmer interviewed at Brong Densuso:

'We make our own nursery because we know the cocoa plant very well and we believe the Amazonia species is very fine. Now if you go to my farm, you will see that there is a difference between the one they call the hybrid and the Amazonia. We have worked with cocoa for a very long time; we were born into it, so we know the difference. When we find a promising seed, we buy that and grow it on our own. As for the hybrid I used some but it did not turn out well. You will be disappointed once you see them on my farm. I even have some Amazonia trees on my farm, which have been on the farm since my father's time and are over 50 years old, but I cannot say the same for the hybrid'.

Quantitative data collected on estimated yields suggested that over 80 per cent of farmers gained low yields on their cocoa of under $400 \mathrm{~kg} / \mathrm{ha}$, while 13 per cent of farmers gained medium yields of between $400-800 \mathrm{~kg} / \mathrm{ha}$, and only 7 per cent of farmers yields of over $800 \mathrm{~kg} / \mathrm{ha}$. There was also an evident inverse relationship between yields and size of cocoa plantations, with larger plantations being less productive. The most likely reason for this is that the larger farmers are unable to expend comparable resources on labour and inputs per hectare as smallholder farmers. They have overreached their capacity to invest in the necessary labour and inputs per hectare to achieve optimal management of cocoa. Labour is the most critical resource. This is supported by the fact that many of the smallholders achieving the highest yields (per hectare) are not using hybrid seeds. At a workshop at Suhum ${ }^{7}$ to present the findings of research to farmers, one of the model farmers invited by the extension services explained that while the application of fertilisers could help achieve higher yields, this depended upon weeding in a timely fashion, since weeds also grew more vigorously when fertilisers were applied. Failure to weed and competition from weeds nullifies the benefits of applying fertilisers.

Farmers with less than 2ha achieved the highest productivity of cocoa within the survey. No farmers with five or more ha gained yields of over $800 \mathrm{~kg} / \mathrm{ha}$ (see Table 6.3). Farm productivity was relatively higher in Suhum-Ayensuano than at Juaboso, which probably reflects more intensive cultivation on smaller plots in 
Suhum-Ayensuano than on the relatively larger farms in Juaboso. The increased intensity of cultivation on smaller plots in Suhum-Ayensuano cannot be attributed to more efficient use of inputs, since farmers at Suhum-Ayensuano largely produced cocoa without any significant usage of inputs, or an increased use of inputs over farmers at Juaboso. Therefore, this can only be attributed to more intensive use of labour in Suhum-Ayensuano, less incidence of disease - or less vulnerability of selected cocoa varieties to disease - or the natural conditions of the soil.

Quantitative data collected on the use of hybrids and yields did not show any correlation between the use of hybrid seed and increased productivity. In fact, the data showed the reverse: that most farms planted with hybrids gained lower average yields than those using Amelonado- or Amazonia-derived seeds (see Table 6.4). This is not necessarily surprising, given the low usage of fertilisers on hybrids (which are heavy feeders on nutrient); the vulnerability of hybrids to disease; and the fact that farmers have selected their own varieties to perform more robustly under conditions where fertilisers and agrochemicals are not being used.

The rise of a class of a significant stratum of mediumscale commercial farmers or of innovatory smallholders using hybrid seeds and inputs and achieving significantly higher yields has not materialised in Suhum-Ayensuano and Juaboso. There has been a very low uptake of new technologies. Most farmers struggle to meet increased labour and input requirements, and often expend most of their resources on hiring labour before they can address input investments. While women tend to use lower quantities of inputs than men, the vast majority of farmers are unable or unwilling to widely use inputs or implement the official recommendations. The high incidence of disease on cocoa plantations often result in farmers allocating any surplus capital to agrochemicals rather than fertilisers, and fertilisers appear to be largely used to address soil fertility issues rather than to attempt to enhance yields. Beyond the lack of availability of capital to purchase inputs, there is a lack of conviction among farmers that the solution to their problems is to adapt high-input packages. There are concerns about the lack of hardiness of hybrid varieties and their adaptability to existing farming system. There is some belief that the older varieties perform better within the existing farm agro-ecology.

\subsection{Changes in the use of inputs}

Before the post-war period few farmers used inputs. The use of hybrid seeds, synthetic fertilisers and agrochemicals only became important in the post-war periodfollowing theemergence ofmajorpestand disease problems in cocoa, particularly the swollen shoot virus.

Table 6.3. The relationship between the size of cocoa plantations and yields per hectare in Suhum-Ayensuano and Juaboso

\begin{tabular}{|c|c|c|c|c|c|c|c|c|c|c|c|c|}
\hline \multicolumn{5}{|c|}{ Both districts } & \multicolumn{4}{|c|}{ Suhum-Ayensuano } & \multicolumn{4}{|c|}{ Juaboso } \\
\hline $\begin{array}{l}\text { Total } \\
\text { land } \\
\text { size in } \\
\text { hectares }\end{array}$ & $\begin{array}{l}\text { Low } \\
\text { (up to } \\
400 \mathrm{~kg} / \\
\text { ha) }\end{array}$ & $\begin{array}{l}\text { Medium } \\
\text { (401- } \\
799 \mathrm{~kg} / \\
\text { ha) }\end{array}$ & $\begin{array}{l}\text { High } \\
\text { (over } \\
800 \mathrm{~kg} / \\
\text { ha) }\end{array}$ & Total & $\begin{array}{l}\text { Low } \\
\text { (up to } \\
400 \mathrm{~kg} / \\
\text { ha) }\end{array}$ & $\begin{array}{l}\text { Medium } \\
\text { (401- } \\
799 \mathrm{~kg} / \\
\text { ha) }\end{array}$ & $\begin{array}{l}\text { High } \\
\text { (over } \\
800 \mathrm{~kg} / \\
\text { ha) }\end{array}$ & Total & $\begin{array}{l}\text { Low } \\
\text { (up to } \\
400 \mathrm{~kg} / \\
\text { ha) }\end{array}$ & $\begin{array}{l}\text { Medium } \\
\text { (401- } \\
799 \mathrm{~kg} / \\
\text { ha) }\end{array}$ & $\begin{array}{l}\text { High } \\
\text { (over } \\
800 \mathrm{~kg} / \\
\text { ha) }\end{array}$ & Total \\
\hline 0.1/1.99ha & 74.4 & 14.6 & 11.0 & 100 & 70.8 & 15.0 & 14.2 & 100 & 82.4 & 13.7 & 3.9 & 100 \\
\hline 2/4.99ha & 80.5 & 12.6 & 6.9 & 100 & 65.3 & 21.4 & 13.3 & 100 & 91.7 & 6.0 & 2.3 & 100 \\
\hline 5/8.99ha & 86.7 & 13.3 & 0.0 & 100 & 66.7 & 33.3 & 0.0 & 100 & 91.7 & 8.3 & 0.0 & 100 \\
\hline 9/65ha & 100.0 & 0.0 & 0.0 & 100 & 100.0 & 0.0 & 0.0 & 100 & 100.0 & 0.0 & 0.0 & 100 \\
\hline Total & 80.3 & 12.8 & 6.9 & 100 & 68.4 & 18.9 & 12.7 & 100 & 90.6 & 7.6 & 1.9 & 100 \\
\hline $\begin{array}{l}\text { Pearson } \\
\text { chi2(6) }\end{array}$ & \multicolumn{4}{|c|}{ 16.3278 $\operatorname{Pr}=0.012$} & \multicolumn{4}{|c|}{$6.1584 \operatorname{Pr}=0.406$} & \multicolumn{4}{|c|}{$7.9846 \operatorname{Pr}=0.239$} \\
\hline
\end{tabular}

Source: Authors' own

Table 6.4. Comparison of yields of planted hybrid and non-hybrid cocoa

\begin{tabular}{|l|c|c|c|}
\hline Cocoa yield $(\mathrm{kg} / \mathrm{ha})$ & No hybrid (\%) & Planted hybrids (\%) & Total (\%) \\
\hline Less than 400kg/ha & 72.2 & 83.7 & 12.8 \\
\hline $401-800 \mathrm{~kg} / \mathrm{ha}$ & 16.0 & 11.5 & 6.9 \\
\hline over $800 \mathrm{~kg} / \mathrm{ha}$ & 11.8 & 4.9 & 493 \\
\hline Total & 144 & 349 & \\
\hline Pearson chi2 $(2)=10.3935 \mathrm{Pr}=0.006$ &
\end{tabular}


The cocoa swollen shoot virus was identified in 1936 in the Eastern Region. Between 1936 and 1938, the Colonial Department of Agriculture destroyed 81,000 trees in a drastic intervention to contain the disease. A Central Cocoa Research Station was established at Tafo to conduct research on the disease. Following the Second World War a major initiative was introduced to contain swollen shoot, which had now extended over an area of about $51,800 \mathrm{~km}^{2}$ in the Eastern Province (now Eastern Region) and into Ashanti (Danquah, 2003). As a result of the disease, the output of cocoa dropped from 300,000 t in 1936 to 200,000 t in the mid-1940s (Danquah, 2003). By 1947, it was estimated that 46 million trees were infected, of which 45 million were in the Eastern Province (Danquah, 2003). By 1955, the Department of Agriculture had destroyed over 40 million cocoa trees on over 92,000 farms. Researchers advocated the replanting of the existing Amolenado tree stock with Amazonian F2 hybrids imported from Brazil, which were first introduced to farmers in 1963. Swollen shoot was also attributed to an ecological complex of interactions between the virus, mealybugs, Pseudococcus insects, ants and forest canopy shade trees preserved by farmers, such as Cola chlamydantha, Cola gigantea, and Ceiba pentandra (Collingwood, 1971). The solutions to these problems have involved the selection of hybrid varieties that favour drier conditions than Amolenado varieties, extension recommendations to limit numbers of shade trees on farms, and increasing the use of agrochemicals and fertilisers. However, these have not really solved the problem in the long-term. Swollen shoot virus continues to be problematic and a number of other diseases and pests continue to trouble cocoa farmers including capsids and black pod disease.

The swollen shoot epidemic of the 1930s-1950s resulted in the decline of cocoa in the Eastern Region, with many large-scale cocoa farmers losing a large proportion of their capital due to the disease. While many of the large-scale farmers migrated to the Western Region, they were unable to rebuild the scale of plantations they possessed due to the increasing value of land and the acquisition of land by larger number of farmers compared to the earlier days of pioneer cocoa farming. As cocoa farming became established within the Gold Coast, chiefs were also more reluctant to sell land outright and released more land on sharecropping contracts to migrant farmers (Boni, 2005). The increasing vulnerability of cocoa to disease and the replacement of the old varieties with modern hybrids has resulted in much higher costs in establishing farms that has also limited the size of farms and created increasing barriers to entry. Many of the smaller farmers in the Eastern Region became increasingly impoverished and migrated to the Western
Region as labourers, or in search of sharecrop tenancies (Arhin, 1988). Higher costs of farming and lower returns have created increasing barriers of entry for women and youth and resulted in farmers in many areas moving into food crop farming.

In addition, the rising costs of inputs have not been reflected in the prices paid to farmers. Consequently, farmers find it difficult or not profitable to follow the recommendations. Thus, the overall trend has been towards smaller cocoa farms, but not more productive farms, since the smallholders often struggle to invest in inputs. In the early 1970s, Collingwood (1971, p. 289) commented:

As a tenfold increase in yield is possible under plantation conditions given capital adequate to support machinery and chemicals, the future seems to lie in big farming. But against this, fluctuations in market price are so wide as to deter the investor even where national land policy or unstable regimes do not debar him. We are left, therefore, with no choice but to support the present small farms and to continue recommending this of that formulation to farm labourers who cannot read what's on the tin.

Several studies continue to point out that la.rge numbers of farmers cannot afford the recommended pest and disease control and farm management practices. Rates of technology adoption are therefore low and pests and diseases a major constraint (Ollennu, Owusu, and Thresh, 1989; Padi and Owusu, 1998). Moreover, 'the recommended methods for control of capsids and black pod disease which involve mainly the use of conventional insecticides and fungicides are now considered to be environmentally unfriendly, posing a threat to both humans and non-target beneficial organisms' (Padi and Owusu, 1998, p. 10).

Several researchers have also expressed misgivings about the performance of hybrids under farming conditions. For instance, Gyau et al. (2015) state:

The dominant full-sun, mono-cropped cocoa system in Côte d'lvoire which increase yields in the short-term led to severe long-term depletion of soil nutrients. Cocoa grown in this way requires rotation to new land after a period of 20-30 years and as a result caused deforestation.

Gockowski and Sonwa (2011, p. 308) also note that farmers who have adopted hybrids have removed shade trees from cocoa, but have been unable to implement the recommended application of inputs and that this leads to environmental stress: 
Of the three main elements of the technology package (improved seed, fertilizer, and low shade) it is often only the elimination of shade that is practiced by resource-poor farmers who are either unable to afford, or lack ready access to the fertilizers and hybrid seed germplasm that are the key factors in the long term sustainability and productivity of this system. 


\section{POLICY FRAMEWORKS}

Since the late 1930s, cocoa has come under the management of a state sector that has been responsible for the marketing of cocoa, regulations and technical interventions in production, which first emerged in the context of Swollen Shoot. The creation of a Cocoa Marketing Board in the colonial period resulted from conflicts between farmers and European cocoa purchasing companies that resulted in the organisation of a cocoa boycott in 1938. Cocoa production reached 581,000t in 1964 and declined to 160,000 t in 1984 as a result of declining producer prices paid by the Cocoa Marketing Board, and declining international prices. Since the early 1980s, there has been significant reforms of the state cocoa sector and pricing structures. While the government has resisted pressures to privatise state control over the international marketing of cocoa, it has liberalised the internal cocoa trade to licensed buyers. The government has retained a central role in setting the price for cocoa but has committed to increasing the percentage of export prices that farmers receive. It also retains a significant role in distributing and subsidising inputs to farmers, particularly in the area of mass spraying of cocoa and support for rehabilitation of cocoa farms with new hybrid varieties. The high quality of Ghanaian production has resulted in premium prices for Ghanaian cocoa and a favourable image for Ghana Cocoa Board (COCOBOD).. Ghanaian cocoa attracts a 3-5 per cent premium price over Côte d'Ivoire Cocoa (Kolavalli and Vigneri, 2017).

COCOBOD uses its control over international cocoa marketing to raise collateral loans to finance its management of cocoa, which has also affected its ability to provide support services to farmers. By 2000, the Ghana producer price had increased by 50 per cent and production to 400,000t, which was also encouraged by more favourable international prices for cocoa in the 2000s. Production expanded to over 950,000t in the mid 2010s but has since dropped following the significant fall in international prices for cocoa, which dropped by 40 per cent in 2017 (World Bank, 2018). The decline of international prices has also affected the ability of COCOBOD to raise syndicated loans on international markets and to provide subsidised inputs to farmers. The Ghanaian government has attempted to maintain high producer prices in a bid to maintain current production levels and has made calls for international producers to raise prices. This has resulted in a debate about the nature of appropriation of value within the commodity chain and the need for better prices for cocoa on the one hand (Fountain and Hietz-Adams, 2015; Odijie, 2018), and on excessive political intervention by government and its failure to adjust local prices to reflect international market fluctuations and on the need to educate farmers on the nature of international price fluctuations on the other hand (World Bank, 2018; Kolavalli and Vigneri, 2017).

Government continues to dominate the international sale of cocoa and provide services to farmers, but the governance of the cocoa sector essentially consists of a public-private partnership. Since the 1990s, there have been substantial changes in the international cocoa sector with three corporations controlling over 60 per cent of global processing (Fold, 2002; Terazono, 2014). These three corporations (Cargill, Barré Callebaut and Olam, which recently bought out 'Archer Daniel Midland's global cocoa supply chain) have all established grinding facilities in Côte d'Ivoire, Ghana, and internationally in Western ports, such as Amsterdam. These corporations have considerable influence over policy in Ghana, running their own individual cocoa programmes, such as Cargill's Cocoa Promise and Nestlé's Cocoa Plan. They have also established umbrella platforms, such as the World Cocoa Foundation, which are highly influential in shaping policies. These transnational corporations have played a powerful role in creating strategic alliances and networks of private service providers in fields of input distribution and financial service providers. This has resulted in the movement of large international corporations into both provision of credit services and input supplies. For instance, in credit services for farmers, international microcredit organisations such as Advans and Opportunity International Savings and Loans are now working within the cocoa sector (Amanor, 2021). Similarly in the supply of inputs, RMG Concept, a subsidiary of Syngenta, has acquired significant agrochemical marketing companies within Ghana (Amanor, 2021). Thus, the government's control over cocoa marketing does not exclude private corporations and transnational 
corporations. Government regulation of cocoa secures the market for international corporations by making it illegal for farmers or unlicensed buyers to trade in cocoa, thus preventing a local market and cottage artisanal sector to develop in cocoa processing, as occurs in other sectors, such as palm oil and shea butter processing, which frequently provide important sources of livelihood for rural women.

Powerful buyer-driven chains that impose powerful international morally-driven demands on the sector that shape policies through threats of sanctions also influence the cocoa sector. During the 1990s, concerns about child-labour were powerful in shaping regulations of cocoa and bringing together government and transnational corporations to work out new modes of governance. In recent years environmental discourses about cocoa's impact on deforestation are shaping interventions within the cocoa sector, leading to the introduction of monitoring and tracking systems that trace production back to farms.

The gains in cocoa production of the 1990s and 2000s have largely resulted from pricing reforms and government subsidisation of inputs, which have encouraged more farmers to rehabilitate old plantations and expand acreages under cocoa. These output gains have probably now met their limits, and the main policy initiatives now attempt to address productivity issues through encouraging the uptake of technical recommendations by farmers. However, the sharp decline in international cocoa prices makes it increasingly difficult for the government to continue to provide subsidised inputs to farmers.

One policy response to these problems has been to call for increasing privatisation of government cocoa services to private market operators (Kolavalli and Vigneri, 2017; World Bank, 2018). However, this overlooks the fact that most cocoa services are provided by the private sector and government subsidies are essentially to private sector distributors. Government subsidised programmes have accompanied a large expansion of private networks of input distributors and linkages between farmer associations the private sector, and initiatives by transnational corporations with government support to implement a network of community-based input and hybrid seed distribution (Amanor, 2021). Odijie (2018) argues that government subsidies of cocoa inputs and seedlings have absorbed most of the surpluse government gains through the marketing of cocoa. In effect, the government is subsidising cocoa for the benefits of international cocoa corporation, instead of looking for viable alternatives to cocoa (Odijie, 2018). Cocoa provides about 10 per cent of the value of agricultural production but accounts for 25 per cent of Ghana's exports (World
Bank, 2018). Outside of cocoa there are few significant export crops, despite the government's attempts to encourage non-traditional exports and diversification into a range of fruit crops (Teye and Torvikey, 2018). A disproportionate share of the agricultural budget is devoted to cocoa. Between 2006 and 2011, the share of public research funding allocated to cocoa was three times greater than the sector's contribution to agricultural output (World Bank, 2018, p. 29). The state's control over cocoa marketing and the lack of access to farmers to freely trade in cocoa products and beans also prevents local processing of cocoa and innovative local cocoa markets to emerge. This severely limits value processing to a select brand of elite small corporations that are unable to effectively compete in global markets dominated by transnational corporations. The World Bank (2018, p. 6) comments on the 'need to add more value to cocoa to reduce being price takers on the international market'.

The present subsidies and controls within the cocoa sector and lack of development of other agricultural alternatives ensures that large numbers of farmers remain within the cocoa sector rather than look for more profitable alternatives. Without addressing the technical problems within cocoa and the inequitable distribution of value, privatisation of cocoa support services may further shift the burden onto farmers, resulting in increasing farm debt as farmers resort to micro-credit service providers to continue to produce cocoa and deal with diseases and pests.

Beyond marketing solutions, other emerging policies deal with technical problems of production within the context of deforestation and climate change initiatives. This has arisen in the context of the association of cocoa with deforestation and international pressures on cocoa corporations. Many of the large transnational cocoa corporations have committed their supply chains to ensure against deforestation. Following the 2017 UN Climate Change and Parties Conference, the governments of Ghana and Côte d'Ivoire together with transnational cocoa companies established the Cocoa and Forest Initiative, which commits the parties to prevent any further conversion of forests to cocoa. To prevent the expansion of cocoa farms they have committed to promoting sustainable intensification. They work in partnership with the Forestry Commission to introduce a tracing system from farm to market for supply chain monitoring, and sustainable cocoa production through promoting cocoa agroforests rather than full-sun based monocultures. They also promote tree planting of shade trees that have economic significance and can provide farmers with an income. However, they continue to work within a framework of intensification of input use, rather than 
promoting a more diversified agroecosystem that can reduce reliance on agrochemicals and dependence on monocultures (Schroth and Harvey, 2007; Gockowski and Sonwa, 2011; Nasser et al., 2020). This focuses on intensifying production and preserving trees without addressing the profound issues of diseases and pests that result in increasing use of agrochemicals that have negative impacts on the forest fauna and farmers capital (Clough, Faust and Tscharntke, 2009; Asigbaase et al., 2019).

The shade trees that are promoted originate in seedlings raised by the forestry services rather than on farmers' own selection of useful forest products based on their long history of interaction with forest. In the past, trees with significant commercial value or potential have been incorporated into cocoa plantations including Kola and Allanblackia (Amanor, 1996; Dawoe et al., 2016). Kola was an important export commodity in the nineteenth century and during the colonial period, but in recent years has been given low priority in agricultural policy. The potential of creating diverse orchard crops within these agroforests to minimise disease problems and hedge against price fluctuations has not received much attention.

These cocoa agroforest options are being developed and coordinated with the Forestry Commission. However, since the 1990s when the Forestry Commission implemented a new forest policy, the Forestry Commission has been associated with dispossessing farmers of tenure rights to forest trees. Before 1994, farmers had rights to timber trees on their farms and the norms allowed them to convert these trees to timber and transact trees with wood cutters and chainsaw operators. During the 1990s, the new Forest Policy brought on farm timber resources under the control of the Forestry Commission, criminalised farmers sale of farm timber and granted rights to timber concessionaires to exploit timber in farms and cocoa plantations. On-farm timber tenure has been redefined by the state, as vested in chiefs who have rights to royalties and held in trust by the state, which has the right to allocate them to concessionaires. This resulted in the rapid offtake of timber in farming areas during the 1990s, which contributed about 80 per cent of timber exports (Amanor, 1999). As a result of damage rendered to cocoa plantations by timber concessionaires, farmers became reluctant to preserve timber trees within their farms, leading to the rapid reduction of shade trees on farms (Amanor, 2005; Marfo et al., 2012; Dawoe et al., 2016; Nasser et al., 2020). Present initiatives enable farmers to register areas in which they have planted trees, but do not give them rights to sell trees independently or to process them into timber. This tends to weaken farmers' future bargaining position against timber companies in selling timber products, since they have no options to sell to markets other than timber contractors with monopoly rights. The impact of these policies is also likely to add more pressures on smallholders, since farmers must now add the costs of managing trees to the already large expenditure on labour and agrochemicals, while the distant future returns to cultivating timber are not very clear. These do not solve the immediate needs of farmers for capital to meet existing costs of inputs, since timber tree cultivation is a long-term investment. The moral discourses on intensifying production to halt deforestation and expansion into new areas, and the needs to introduce surveillance over farm production also add to the pressures on smallholders. Those least likely to benefit from these arrangements include the large numbers of cocoa planters who acquire land on sharecrop arrangements (Nasser et al., 2020).

The alliance between the forestry and cocoa sectors operates with the remit of controlling farmers into predefined project-determined policy directives rather than searching for new creative opportunities. These recent cocoa agroforest initiatives provide little scope for the considerable knowledge of farmers of agroforesty techniques and species diversity to be incorporated into conservation initiatives. The concerns with intensifying cocoa production also prevent the development of options that attempt to diversify production as a means of hedging against price fluctuations and vulnerability to disease and pest epidemics. They do not consider alternative frameworks to intensive monocultural cocoa hybrid plantations that can include more diverse agroforestry systems, incorporating a variety of fruit trees and indigenous forest species alongside cocoa (Gyau, 2015; Asigbaase et al., 2019). More diversified agroforests can lay the basis for meeting the needs of many poorer farmers for less intensive input cocoa systems, which hedge against market shocks of fluctuating prices for cocoa, while genuinely addressing and ameliorating some of the environmental effects of expansive monocultural production and the high costs of agrochemicals. 
The cocoa sector in Ghana provides over 100 years of experience of commercial development. Over this period, cocoa has been transformed from a pioneer forest crop associated with the opening up of new forests and minimal use of inputs, to a crop associated with intensive cultivation and a high usage of inputs by smallholder farmers on rehabilitated old forest land. Replanting of cocoa has not been an easy venture and a common experience is for the frontier to shift to new areas and old frontiers to move into other crops. In Ghana, this has only been partially the case, and while new crops have been taken up in some areas of the forest, such as the new oil palm belt in the Kade area, many areas lack a viable alternative to cocoa. This is partly because of the government's commitment to cocoa, its allocation of an inordinately large part of the agricultural budget to cocoa, and its development of a large state sector committed to marketing of cocoa. While this resulted in some successes in turning around the cocoa sector, and raising outputs to an all-time high, the cocoa sector continues to be highly vulnerable to market fluctuations, as reflected in the recent sharp falls in prices. These threaten the ability of government to continue to provide support to farmers in input subsidies and packages for replanting. Cocoa continues to be plagued by high incidences of diseases that drastically affect yield and force farmers to expend considerable resources on agrochemicals. As a result, large numbers of farmers are often unable to follow extension recommendations, and the outlays on inputs and labour are not reflected in the prices that farmers receive. Due to these constraints, a medium strata of farmers investing in inputs and experiencing significantly improved yields has failed to materialise in a significant way, and the cocoa sector is dominated by large numbers of smallholders struggling to acquire inputs and hire labour. Entry barriers are high, resulting in the emergence of sharecropping among farmers who cannot afford land or gain access to land and among farmers with land who cannot afford the costs of rehabilitating plantations. Farmers with larger areas of land often cannot afford the costs of hired labour and inputs, and often gain lower yields than farmers with smaller holdings. The wealthy cocoa farmers with multiple large holdings in several settlements are no longer common in cocoa as they were up until the 1960s, and many of the wealthy cocoa farmers from the colonial period have moved into other sectors. A significant number of descendants of cocoa farmers have moved into the informal artisanal and trading sectors in the many small towns within the cocoa belt, including a large proportion of women who experience difficulties in entering cocoa production. Since the state monopolises trading in cocoa for the export sector, there are no opportunities for rural processing of cocoa products to emerge. Many youths work as casual labourers since they have limited options of gaining land and capital to invest in cocoa, and because the labour-intensive activities of replanting cocoa result in high demand for hired labour. Recently, environmental objectives have been added to cocoa projects. These largely respond to international narratives of deforestation and Reducing Emissions from Deforestation and Forest Degradation in Developing Countries (REDD+) initiatives. These are appended onto the frameworks of agricultural intensification, in which intensification solves deforestation by halting the need of farmers to move into forested land and forest reserves to maintain their output. This adds the planting of shade trees to intensified cocoa production as a potential REDD+ friendly activity. However, this fails to address or resolve the ecological crisis of the vulnerability of cocoa monocultures to disease and pests that lies at the heart of cocoa production, and which originally initiated the rise of agricultural modernisation in cocoa in the 1940s. It also fails to develop a more inclusive approach to cocoa that builds upon the knowledge and experience of farming communities of forests and local markets in forest products. 
Africa Research Bulletin (2019) 'Cocoa Côte d'Ivoire/Ghana', Africa Research Bulletin 56(7): 22662.

Amanor, K.S. (2021) 'Transnational Corporations, Financialization and Community Development in West African Cocoa', Community Development 56(1): 59-78.

Amanor, K.S. (2010) 'Family Values, Land Sales and Agricultural Commodification in South-Eastern Ghana', Africa 80(1): 104-25.

Amanor, K.S. (2008) 'The Changing Face of Customary Land tenure', in J. Ubink and K.S. Amanor (eds.) Contesting Land and Custom in Ghana: State, chief and citizen. Leiden: Leiden University Press.

Amanor, K.S. (1999) Global Restructuring and Land rights in Ghana: Forest food chains, timber and rural livelihoods. Uppsala: Nordic African Institute.

Amanor, K.S. (1996) The Management of Trees on Farms: The perspectives of farmers. Kumasi: Ghana Forestry Department.

Amanor, K.S. (1994) The New Frontier: Farmers' responses to land degradation. A West African case study. London: Zed Books

Amanor, K.S., Yaro, J.A. and Teye, J.K. (2020) Long-Term Change and Agricultural Commercialisation in Ghanaian Cocoa, APRA Working Paper 31. Brighton: Future Agricultures Consortium. Available at: https://opendocs.ids. ac.uk/opendocs/handle/20.500.12413/15270 (Accessed: 1 November 2021).

Arhin, K. (1988) 'Economic Differentiation Among Ghanaian Migrant Cocoa Farmers', Research Review NS 4(1): 10-18.

Arhin, K. (1980) 'The Economic and Social Significance of Rubber Production and Exchange on the Gold and Ivory Coasts, 1880-1900', Cahiers D'Études Africaines 20(77-78): 49-62. Available at: https://www.persee.fr/ docAsPDF/cea_0008-0055_1980_num_20_77_2350.pdf (Accessed: 2 March 2020).

Asare, R., Afari-Sefa, V., Osei-Owusu, Y. and Pabi, O. (2014) 'Cocoa agroforestry for increasing forest connectivity in a fragmented landscape in Ghana', Agroforestry Systems 88: 1143-1156.

Asare, R. and Anders, R. (2016) 'Tree diversity and canopy cover in cocoa systems in Ghana', New Forests 47:287-302.

Asigbaase, M., Sjorgestern, S., Lomax, B.H. and Dawoe, E. (2019) 'Tree Diversity and its Ecological Importance Value in Organic and Conventional Cocoa in Ghana', Plos One 14(1): e0210557.

Austin, G. (2005) Labour, Land and Capital in Ghana: From Slavery to Free Labour in Asante (1807-1956). Woodbridge: Boydell and Brewer Ltd.

Beckett, W.H. (1944) Akokoaso: A Survey of a Gold Coast Village. Monographs on Social Anthropology 10. London: London School of Economics.

Boni, S. (2005) Clearing the Ghanaian Forest: Theories and Practices of Acquisition, Transfer and Utilisation of Farming Titles in the Sefwi-Akan Area. Legon: Institute of African Studies, University of Ghana.

Bray, F.R. (1959) Cocoa development in Ahafo, West Ashanti. Legon: Faculty of Agriculture, University of Ghana.

Bymolt, R., Laven, A. and Tyszler, M. (2018) Demystifying the Cocoa Sector in Ghana and Côte d'Ivoire.

Amsterdam: The Royal Tropical Institute (KIT). 
Chauveau, J-P. and Léonard, É. (1996) 'Côte d'Ivoire's Pioneer Fronts: Historical and Political Determinants of the Spread of Cocoa Cultivation' in W.G. Clarence-Smith (ed.) Cocoa Pioneer Fronts since 1800: The role of smallholders, planters and merchants. Basingstoke: Macmillan.

Clough, Y., Faust, H. and Tscharntke, T. (2009) 'Cacao Boom and Bust: Sustainability of agroforests and opportunities for biodiversity conservation', Conservation Letters 2: 197-205.

Clough, Y., Dwi Putra, D., Pitopang, R., and Tscharntke, T. (2009) 'Local and Landscape Factors Determine Functional Bird Diversity in Indonesian Cacao Agroforestry' Biology and Conservation 142: 1032-1041.

Collingwood, C.A. (1971) Cocoa capsids in West Africa. Report of the International Capsid Research Team 196571. London: International Office of Cocoa and Chocolate Alliance.

Danquah, F.K. (2003) 'Sustaining a West African Cocoa Economy: Agricultural science and the swollen shoot conatagion in Ghana, 1936-1965', Journal of African Economic History 31: 43-74.

Daviron, B. and Ponte, S. (2005) The Coffee Paradox: Global markets, commodity trade and the elusive promise of development. London: Zed Books.

Dawoe, E.L.K., Asante, W., Acheampong, E. and Bosu, P.P. (2016) 'Shade Tree Diversity and Aboveground Carbon Stocks in Theobroma Cacao Agroforestry Systems: Implications for REDD+ implementation in a West African cacao landscape', Carbon Balance and Management, 11(1)

Deininger, K. (2003) Land Policies for Growth and Poverty Reduction. Washington: World Bank; Oxford: Oxford University Press.

Diao, X., Cossar, F., Houssou, N. and Kolavalli, S. (2014) 'Mechanization in Ghana: Emerging Demand, and the Search for Alternative Supply Models', Food Policy 48: 168-181.

Dormon, E.N.A., Huis, A.V., Leeuwis, C., Obeng-Ofori, D. and Saku-Dawson, O. (2004) 'Causes of Low Productivity in Cocoa in Ghana: Farmers' perspectives and insights from research', NJAS-Wageningen Journal of Life Sciences 52(3-4): 237-259.

Fairtrade International (2018) Cocoa farmer income: the household income of cocoa farmers in Côte $d^{\prime \prime} / v o i r e$ and strategies for improvement. Available at: https://files.fairtrade.net/publications/2018_ FairtradeCocoaFarmerlncomeCDI.pdf (Accessed: 20 June 2020).

Field, M.J. (1948) Akim Kotoku: An Oman of the Gold Coast, London: Crown Agents.

Fold, N. (2002) 'Lead firms and competition in "bi-polar" commodity chains: grinders and branders in the global cocoa-chocolate industry', Journal of Agrarian Change 2(2): 228-247.

Fountain, A.C. and Huetz-Adams, F. (2015) 'Cocoa Barometer 2015', Cocoa Barometer [online]. Available at: http://www.cocoabarometer.org/ (Accessed: 5 December 2019).

Gockowski, J. and Sonwa, D. (2011) 'Cocoa Intensification Scenarios and their predicted impact on CO Emissions: Biodiversity conservation and rural livelihoods in the Guinea rainforest of West Africa', Environmental Management 48(2): $7-21$.

Gyau, A., Smoot, K., Diby, L. and Kouame, C. (2015) 'Drivers of Tree Presence and Densities: The case of cocoa agroforestry systems in the Soubre Region of Republic of Côte D'Ivoire', Agroforestry Systems 81: 149-161.

Hainmueller, J., Hiscox, M. and Tampec, M. (2011) Sustainable Development for Cocoa Farmers in Ghana. London: International Growth Centre, London School of Economic and Political Science.

Hall, J.B., and Swaine, M.D. (1981) Distribution and Ecology of Vascular Plants in a Tropical Rain Forest. The Hague: Junk.

Hill, P. (1963) The Migrant Cocoa-Farmers of Southern Ghana: A Study in Rural Capitalism. Cambridge: Cambridge University Press 
Hill, P. (1956) The Gold Coast Cocoa Farmer: A Preliminary Survey. London: Oxford University Press.

Hill, P. and McGlade, C. (1957) An Economic Survey of Cocoa Farmers in Northern Akim Abuakwai. Cocoa Research Series Vol. 1. Legon: Economic Research Division, University College of Ghana.

Jayne, T.S., Muyanga, M. Wineman, A., Ghebru, H., Stevens, C., Stickler, M., Chapoto, A., Anseeuw, W., van der Westhuizen, D. and Nyange, D. (2019) 'Are Medium-Scale Farms Driving Agricultural Transformation in SubSaharan Africa?', Agricultural Economics 50: 75-95.

Johnson, M. (1964) 'Migrants Progress' Part 1. Bulletin of the Ghana Geographical Society 9(2): 4-27.

Kolavalli, S. and Vigneri, M. (2017) The Cocoa Coast: The board-managed cocoa sector in Ghana. Washington: International Food Policy Research Institute.

Laird, S.A., Awung, G.L. and Lysinge, R.J. (2007) 'Cocoa farms in the Mount Cameroon region: biological and cultural diversity in local livelihoods', Biodiversity and Conservation 16(8): 2401-2427.

Nasser, F., Maguire-Rajpaul, V.A., Dumenu, W.K. and Wong, G.Y. (2020) 'Climate-Smart Cocoa in Ghana: How ecological modernisation discourse risks side-lining cocoa smallholders' Frontiers in Sustainable Food Systems $4(73): 1-17$.

Odijie, M. (2018) 'Sustainability Winners and Losers in Business-biased Cocoa Sustainability Programmes in West Africa', International Journal of Agricultural Sustainability 16(2): 214-227.

Okali, C. (1983) Cocoa and Kinship in Ghana: The Matrilineal Akan of Ghana. London: KPI.

Okali, C. and Kotey, R.A. (1971) Akokoaso: A Resurvey, Volume 15 Technical Publication Series. Legon: Institute of Statistical, Social and Economic Research, University of Ghana.

Ollennu, L.A.A., Owusu, G.K. and Thresh, J.M. (1989) 'The control of cocoa swollen shoot disease in Ghana', Cocoa Growers' Bulletin No. 42, December, 1989: 25-35.

Padi, B. and Owusu, G.K. (1998) 'Towards an integrated pest management for sustainable cocoa production in Ghana', in: Proceedings of the 1st Sustainable Cocoa Workshop, 20 March to 3 April 1998, Panama. Available at: https://nationalzoo.si.edu/scbi/migratorybirds/research/cacao/padi.cfm (Accessed: 1 November 2021).

Ruf, F.O. (2011) 'The Myth of Complex Cocoa Agroforests: The case of Ghana', Human Ecology 39: $373-388$.

Ruf, F. (2010) 'From Forest Rent to Tree-Capital: Basic 'laws' of cocoa supply', in F. Ruf and P.S. Siswoputranto (eds.) Cocoa Cycles: The economics of cocoa supply. Great Abington: Woodhead Publishing Ltd.

Ruf, F.O. and Bini, S. (2011) 'Cocoa and Fertilizers in West-Africa', paper presented at the International Supply Management Congress, Amsterdam, 11-16 December. Available at: www.researchgate.net/ publication/326093032_Cocoa_and_fertilizers_in_West-Africa (Accessed: 1 April 2020).

Ruf, F. and Schroth, G. (2015) 'Economic and Ecological Aspects of Diversification of Tropical Tree Crops', in F. Ruf and G, Schroth (eds.) Economics and Ecology of Diversification: The case of tropical tree crops. Dordrecht: Springer.

Schroth, G. and Harvey, C.A. (2007) 'Biodiversity Conservation in Cocoa Production Landscapes: An overview', Biodiversity and Conservation 16(8): 2237-2244.

Terazono, E. (2014) 'Welcome to the world of big chocolate, commodity note', Financial Times [online], 18 December. Available at: https://www.ft.com/content/80e196cc-8538-11e4-ab4e-00144feabdc0 (Accessed: 20 September 2021).

Teye, J.K. and Torvikey, D. (2018) The Political Economy of Agricultural Commercialisation in Ghana: A Review, APRA Working Paper 15, Brighton: Future Agricultures Consortium. Available at: https://opendocs.ids.ac.uk/ opendocs/handle/123456789/13953 (Accessed: 4 March 2020).

Urquhart, D. (1961) Cocoa. London: Longmans Green. 
World Bank (2018) Third Ghana Economic Update: Agriculture as an engine of growth and jobs creation. Washington: World Bank Africa Region. Available at: https://documents1.worldbank.org/curated/pt/113921519661644757/ pdf/123707-REVISED-Ghana-Economic-Update-3-13-18-web.pdf (Accessed: 7 October 2021).

Yaro, J.A. (2012) 'Re-inventing Traditional Land Tenure in the Era of Land Commoditization: Some consequences in periurban northern Ghana', Geografiska Annaler: Series B, Human Geography 94(4): 351-368. 
Amanor, K., Yaro, J. and Teye, J. (2021) Long-Term Patterns of Change in the Commercialisation of Cocoa in Ghana: Forest Frontiers and Technological Transformation. APRA Working Paper 76. Brighton: Future Agricultures Consortium

(c) APRA 2021

ISBN: 978-1-78118-893-4

DOI: 10.19088/APRA.2021.045

\section{(cC) BY-NC-ND}

This is an Open Access report distributed under the terms of the Attribution-Non Commercial-No Derivs 4.0 Unported (CC BY-NC-ND 4.0) Attribution - You must give appropriate credit, provide a link to the license, and indicate if changes were made. You may do so in any reasonable manner, but not in any way that suggests the licensor endorses you or your use. NonCommercial — You may not use the material for commercial purposes. NoDerivatives - If you remix, transform, or build upon the material, you may not distribute the modified material. You are free to: Share - copy and redistribute the material in any medium or format.

https://creativecommons.org/licenses/by-nc-nd/4.0/legalcode

If you use the work, we ask that you reference the APRA website (www.future-agricultures.org/apra/) and send a copy of the work or a link to its use online to the following address for our archive: APRA, Future Agricultures Consortium, University of Sussex, Brighton BN1 9RE, UK (apra@ids.ac.uk)

All APRA Working Papers go through a review process before publication.

\section{@creative}

\section{DO YOU HAVE COMMENTS ON THIS PAPER?}

We would welcome your feedback on this working paper!

To provide brief comments, please follow this link to our short APRA Working Paper Feedback form: https://goo.gl/forms/1iVnXhhrIGesfR9

Agricultural Policy Research in Africa (APRA) is a programme of the Future Agricultures Consortium (FAC) which is

generating new evidence and policy-relevant insights on more inclusive pathways to agricultural commercialisation in sub-Saharan Africa. APRA is funded with UK aid from the UK Foreign, Commonwealth \&

Development Office (FCDO) and will run from 2016-2022.

The APRA Directorate is based at the Institute of Development Studies (IDS), UK (www.ids.ac.uk), with regional hubs at the Centre for African Bio-Entrepreneurship (CABE), Kenya, the Institute for Poverty, Land and Agrarian Studies (PLAAS), South Africa, and the University of Ghana, Legon. It builds on more than a decade of research and policy engagement work by the Future Agricultures Consortium (www.future-agricultures.org) and involves more than 100 researchers and communications professionals in Africa, UK, Sweden and USA. 